\section{Application of Solid Expandable Tubulars in the Petroleum Industry}

Rudarsko-geološko-naftni zbornik

(The Mining-Geology-Petroleum Engineering Bulletin) UDC: 622.2

DOI: 10.17794/rgn.2022.1.14

Original scientific paper

\author{
Nediljka Gaurina-Međimurec; Pavao Mesarić ${ }^{2}$ \\ ${ }^{1}$ Faculty of Mining, Geology and Petroleum Engineering, Pierottijeva 6, 10000 Zagreb, Croatia \\ ${ }^{2}$ ENSOLX d.o.o., Hebrangova ul. 30, 10000 Zagreb, Croatia
}

\begin{abstract}
The development of solid expandable tubular (SET) technology and products (open hole liner, open hole clad, cased hole liner, liner hanger, internal casing patch, etc.) has enabled operators to plan well design in a new way and solve various problems that arise during drilling and exploitation on land and offshore. By including an expandable open hole liner, monobore open hole liner or monobore openhole clad in well design, it is possible to achieve a slim hole design and/or resolve unwanted situations that occur during the drilling of problem zones with minimal hole size reduction and reach hydrocarbon reserves which cannot be achieved economically by conventional technology. By installing an expandable cased hole liner or internal casing patch in production wells to cover the intervals of a corroded casing or to close old perforations, it is possible to extend the life cycle of a production well and increase the final hydrocarbon recovery and speed up the return on investment. The aim of this paper is to systematically review the relevant literature and give an overview of solid expandable tubular technology and its applications in the petroleum industry, as well as the cementing technology of open hole expandable liners. The available data for 21 case studies of SET application in onshore and offshore wells were analyzed in detail. Based on an extensive review of the literature and analyzed data, it can be concluded that SET technology is being successfully applied worldwide and that expandable liners with a diameter of $114.3 \mathrm{~mm}$ to $339.72 \mathrm{~mm}$ are being run in wells to ever greater depths (up to $5166 \mathrm{~m}$ ) and in ever more extreme downhole conditions.
\end{abstract}

Keywords:

expandable tubulars; cone expander; liner; liner hanger; cementing

\section{Introduction}

During drilling, operators occasionally encounter unplanned situations (lost circulation zones, sub-salt rubble zones, formation-related wellbore instability, high pressure zones, differential or mechanical pipe sticking, fractured reservoirs) that are usually resolved by running a standard casing, which in turn results in a reduction of the diameter (Gaurina-Medimurec, 2005; Simon et al., 2005; Gaurina-Međimurec et al., 2006, Pašić et al., 2007; Shiri and Shiri, 2021). Running an expandable liner in the wellbore prevents or reduces the telescopic (narrowing) effect of conventional casing programs and allows the running of one or two additional strings in the well. By introducing expandable tubulars into drilling practice, existing wells could now be completed by including an additional casing without increasing top-hole design or compromising on the planned completion size (Stewart et al., 1999; Stringer and Farley, 2013). Solid expandable tubular (SET) technology has been used to improve well design in the plan-

Corresponding author: Nediljka Gaurina-Međimurec nediljka.gaurina-medjimurec@rgn.unizg.hr ning phase, to mitigate drilling hazards in drilling and completion phase, and to overcome mature-field challenges in the production phase (Demong and Rivenbark, 2003; Escobar et al., 2003; Rivenbark et al., 2004; Carrillo et al., 2016; Ben Aissa and Benabdelhafid, 2017).

The application of the solid expandable tubular (SET) technology in the subsurface environment has the potential of significantly reducing surface and subsurface costs and increasing the return on operating companies' investments (Filippov et al., 1999; Owoeye et al., 2000; Dupal et al., 2000; Ruggier et al., 2001; Gusevik and Merritt, 2002; Demong et al., 2004; Ruan and Maurer, 2005; Morrison et al., 2005; Miessner et al., 2006; Schultz et al., 2008; Al-Abri and Pervez, 2013; McCormick et al., 2013: Kupresan, 2014). Expandable tubulars offer the potential for a "monoborehole" (or monodiameter borehole) and drilling to depths no longer limited by the initial hole diameter (Benzie et al., 2000; Campo et al., 2003). Certain critical wells, in which the drilling environment requires more casing points than there are casing sizes (e.g., ultra-deepwater wells), cannot be drilled to their objectives without solid expandable tubular technology (Dell et al., 2019). 
SET technology refers to methods involving the expansion of continuous tubulars, without slots or perforations, applying a fixed cone expansion tool or rotary expansion tools with fixed or compliant roller systems (Innes et al., 2004).

The first commercial running of Solid Expandable Tubulars (SET) was performed by Chevron in a well in the shallow waters of the Gulf of Mexico in November 1999 (Grant and Bullock, 2005). The objective of the first commercial use of solid expandable tubulars was to lower costs by decreasing casing and hole sizes compared to conventional technology. A $300.23 \mathrm{~m}$ (985 ft) length of $193.68 \mathrm{~mm}$ (75/8 in.) SET liner was run on an $88.9 \mathrm{~mm}\left(3 \frac{1}{2} \mathrm{in}\right.$.) by $127 \mathrm{~mm}$ (5 in.) tapered inner string to a measured depth of 4,002.33 m (13,131 ft). The well was circulated, and cement pumped, followed by the latch-down plug (dart). Once the latch-down plug landed, the expansion process took about $4 \frac{1}{2}$ hours, with pressures averaging 27.58 $\mathrm{MPa}\left(4,000 \mathrm{lb}_{\mathrm{f}} / \mathrm{in}^{2}\right)$, and a maximum pressure of $33.09 \mathrm{MPa}\left(4,800 \mathrm{lb}_{\mathrm{f}} / \mathrm{in}^{2}\right)$ when the hanger joint was expanded against the $244.475 \mathrm{~mm}$ ( $95 / 8$ in.) casing. The initial liner length of $300.23 \mathrm{~m}$ (985 $\mathrm{ft})$ shortened to $288.341 \mathrm{~m}(946 \mathrm{ft})$, as a result of the expansion process, putting the top of the SET liner at a measured depth (MD) of 3,714 m (12,185 ft) (Dupal et al., 2001).

Gupta and Banerjee (2007), with the aim of reducing the very high rig costs, presented the idea of applying expandable tubulars in casing while drilling (CwD) in extended reach wells, mainly in deep waters. In addition to deep-water applications, expandable products can be used to rejuvenate land-based or cased-hole wells too. The advantage of using expandable tubulars in landbased, cased-hole oil wells is that it allows the restoration of these old wells that might have been abandoned in the past (Brunner, 2002; Nor et al., 2002).

Over the years, casing corrosion occurs in oil and gas wells, so companies that own them are looking for ways to extend their productive lives. This is now made possible by lining the corroded casing from the inside using expandable pipes (Al-Umran et al., 2008; Badrack et al., 2005; Bargawi et al., 2005; Benzi et al., 2018).

After its first commercial application in 1999, for more than 20 years, SET technology has achieved significant application in the oil industry (Owoeye et al., 2000; Waddell and Schuurmans, 2004; Marketz et al., 2005; Jennings, 2008; DeLange et al., 2011; Mason et al., 2011; Tao, 2015; Wold et al., 2020). The solutions currently offered by SET technology are based on extensive analytical modelling, laboratory tests and large field tests.

In the Ghawar oilfield of Saudi Arabia, in the Ain Dar497 well, Saudi Aramco has successfully applied a 152.4 mm x $177.8 \mathrm{~mm}$ (6 in. $\mathrm{x} 7$ in.) bi-center bit to drill the build section in which the $138.7 \mathrm{~mm} \times 177.8 \mathrm{~mm}\left(5^{1 / 2} \mathrm{in}\right.$. $\mathrm{x} 7$ in.) solid expandable open hole liner was run and cemented across the gas cap to avoid gas production and to reduce the risk of a kick or causing lost circulation while drilling the horizontal hole below it (Morrison et al., 2005). The solid expandable open hole liner replaced the $177.8 \mathrm{~mm}$ ( $7 \mathrm{in}$.) conventional liner and allowed for the continuation of drilling a $155.58 \mathrm{~mm}$ (61/8 in.) hole using a $138.7 \mathrm{~mm} \times 155.58 \mathrm{~mm}\left(5 \frac{1}{2}\right.$ in. $\times 6 \frac{1}{8}$ in.) bi-center bit to a measured depth (MD) of $3657.6 \mathrm{~m}$ (12,000 ft). Simultaneous use of a solid expandable open hole liner and bicenter bit in the original drilling plan resulted in a reduction of the typical well design by an entire casing size and the total well cost by $23 \%$, with a reduction of the overall environmental impact and a reduction of total rig time by 9 days (Morrison et al., 2005).

The world's first $406.4 \mathrm{~mm}$ (16 in.), $1678.3 \mathrm{~N} / \mathrm{m}$ (115 $\mathrm{lb}_{\mathrm{f}} / \mathrm{ft}$ ) expandable open hole liner (OHL) system was installed in April 2012 in a well in the Uthmaniyah Field, in Saudi Arabia, thus launching a significant change in the application of large diameter liners from deeper contingency applications to planned hole-conservation designs in the upper wellbore (Shaikh et al., 2013). The purpose of running the OHL was the zonal isolation of reservoirs with different pore pressure, while minimizing the loss of hole diameter to maintain the original wellbore design and drilling tools. An expandable open hole liner was run to a depth of $520.6 \mathrm{~m}$ (1,708 ft) (pre-expanded length), anchored into the $473.075 \mathrm{~mm}$ (185/8 in.) casing and successfully cemented and expanded. In addition, other benefits have been achieved, such as an increase in rate of penetration, the elimination of the need for two-stage cementing, and a reduction of hook load associated with long casing strings (Shaikh et al., 2013).

In Kazakhstan, the first expandable open hole liner was installed in 2016 (Aidoo et al., 2016). $138.7 \mathrm{~m} \mathrm{(51/2} \mathrm{in.)}$ expandable OHL was selected and applied in an old well (in the side-track, below the existing $177.8 \mathrm{~mm}$ (7 in.) production casing shoe) as a contingency option. The objectives were to abandon the existing openhole reservoir section, isolate the zones of different pressures, avoid loss of circulation in low pressure zones, and allow well deepening to reach the Pre-Tula reservoir. The open hole section cased with the $138.7 \mathrm{~m}$ (51/2 in.) expandable liner was $1,300 \mathrm{~m}$ long, and the OHL was installed to a depth of $5,167 \mathrm{~m}$. The total length of the OHL before expansion was 1,403 $\mathrm{m}$ (post expansion length was 1,366 $\mathrm{m}$ due to shrinkage), so it was considered at the time of running the longest $138.7 \mathrm{~m}$ (51/2 in.) expandable OHL globally (Aidoo et al., 2016). After cementing, the expandable OHL was expanded, leaving a $132.08 \mathrm{~mm}$ (5.2 in.) internal diameter ID (129.89 mm (5.114 in.) Drift ID) which allowed for the drilling of a reservoir section with a $127 \mathrm{~mm}$ (5 in.) bit to the planned total depth, and facilitate running and cementing of the $88.9 \mathrm{~mm} \times 114.3 \mathrm{~mm} \mathrm{(31/2} \mathrm{in.} \mathrm{m} \mathrm{4} \frac{1}{2}$ in.) production liner. The objectives were achieved with no operational or safety incidents, and the field life was extended (Aidoo et al., 2016).

The world's first $177.8 \mathrm{~mm}$ (7 in.) expandable isolation system was successfully installed in 2005 in a trial 
well in south Texas (ULR 9). The longest openhole system installed to date was a $193.67 \mathrm{~mm} \times 244.47 \mathrm{~mm}(7 \% / 8$ in. $\mathrm{x} 95 / 8$ in.) system of 2,114 m (6,935 ft) (ULR 2).

The risk of an expandable liner getting stuck during its running in the borehole, to isolate a zone of total loss circulation and tight spots, can be successfully prevented by adding expandable bow-spring centralizers. In February 2014, the addition of expandable bow-spring centralizers provided, to a major operator in the Middle East, the solution with pre- and post-expansion stand-off that allowed the $138.7 \mathrm{~m}\left(5 \frac{1}{2} \mathrm{in}\right.$.) open hole expandable liner (liner length was $751 \mathrm{~m} ; 2,464 \mathrm{ft}$ ) to be run, in the side-track/whipstock well type, to its full setting depth (2,336 m; 7,664 ft), cemented, and expanded (ULR 1). To install an expandable open hole liner, it is first necessary to drill an over-gauge hole. After the liner is lowered to the setting depth with a cone expander in the launcher at the bottom of liner, it is cemented and expanded. Expanding the open hole liner into the unset cement slurry helps ensure a good bond of the liner to the set cement and the set cement to the wellbore (Schultz et al., 2008). According to Schultz et al., for operators to

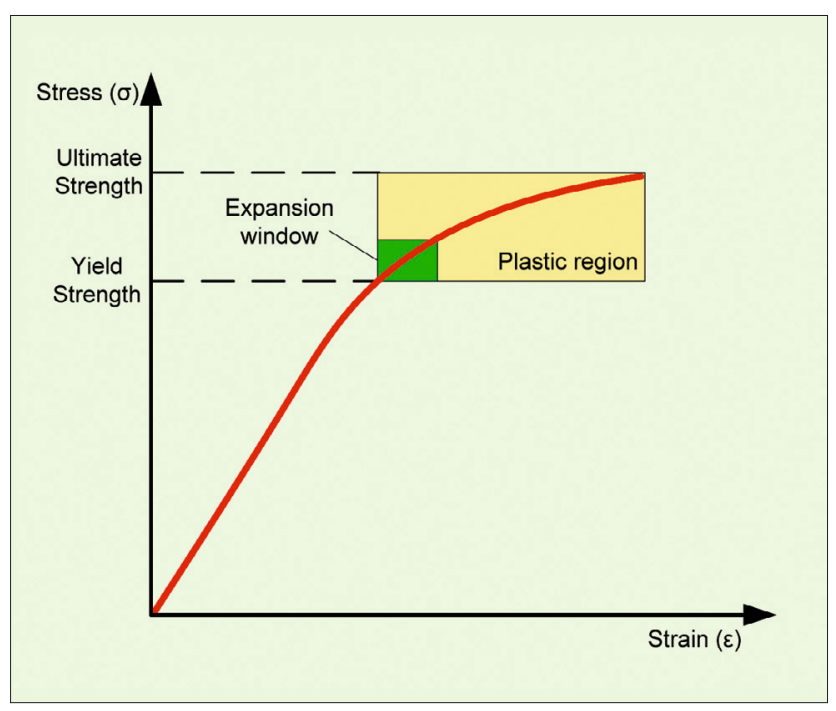

Figure 1: Stress/strain curve of solid expandable tubular and tubular's expansion window take full advantage of expandable open hole liner technology, a successful cementing job is critical (Schultz et al., 2008).

Kupresan et al. (2014) investigated the potential effect of expandable-casing technology on the cement sheath and remediation of the sustained casing pressure (SCP) caused by microannular gas migration. Based on the laboratory tests, they concluded that casing expansion proved to be a successful technique for the mitigation of microannular gas migration under the tested conditions. The seal of the microannulus was apparent immediately post-expansion and was still effective even 60 days after the expansion. With the growth of the SET technology and experience, solid expandable tubular jobs are becoming routine for use in wells, both onshore and offshore.

This paper provides an overview of solid expandable tubular technology and its applications in the field practice with an emphasis on cementing technology of open hole expandable liners.

\section{The basic concept of expandable tubular technology}

The concept of expandable solid tubular technology is based on cold-working steel down hole. This process deforms the tube beyond its elastic limit, within the tubular's plastic region resulting in permanent deformation and increase in the diameter of the pipe (Filippov et al., 1999; Haut and Sharif, 1999; Cameron et al., 2013; Park et al., 2015). Figure 1 shows the stress/ strain curve of solid expandable tubular and expansion window inside the tubular's plastic region. After linear expansion of the pipe, its strength increases and its ductility decreases (Cameron et al., 2013).

The liner expansion process takes place thanks to the use of an expansion tool (see Figure 2) for which different names are used in literature, such as pig (Bybee, 2000), mandrel (Daigle et al., 2000), cone expander (Ruan and Maurer, 2005), cone (Cameron et al., 2013), mandrel or conical mandrel (Al-Abri and Per-
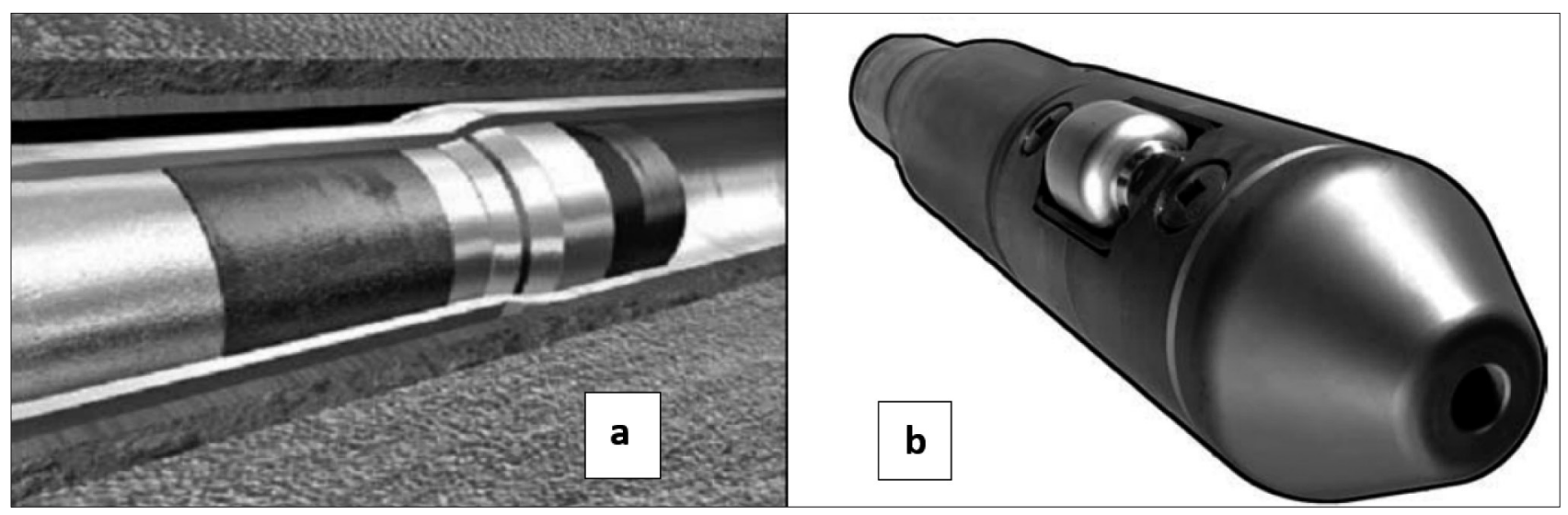

Figure 2: Fixed cone expander (a) and rotary compliant expansion tool (b) (Innes et al., 2004) 


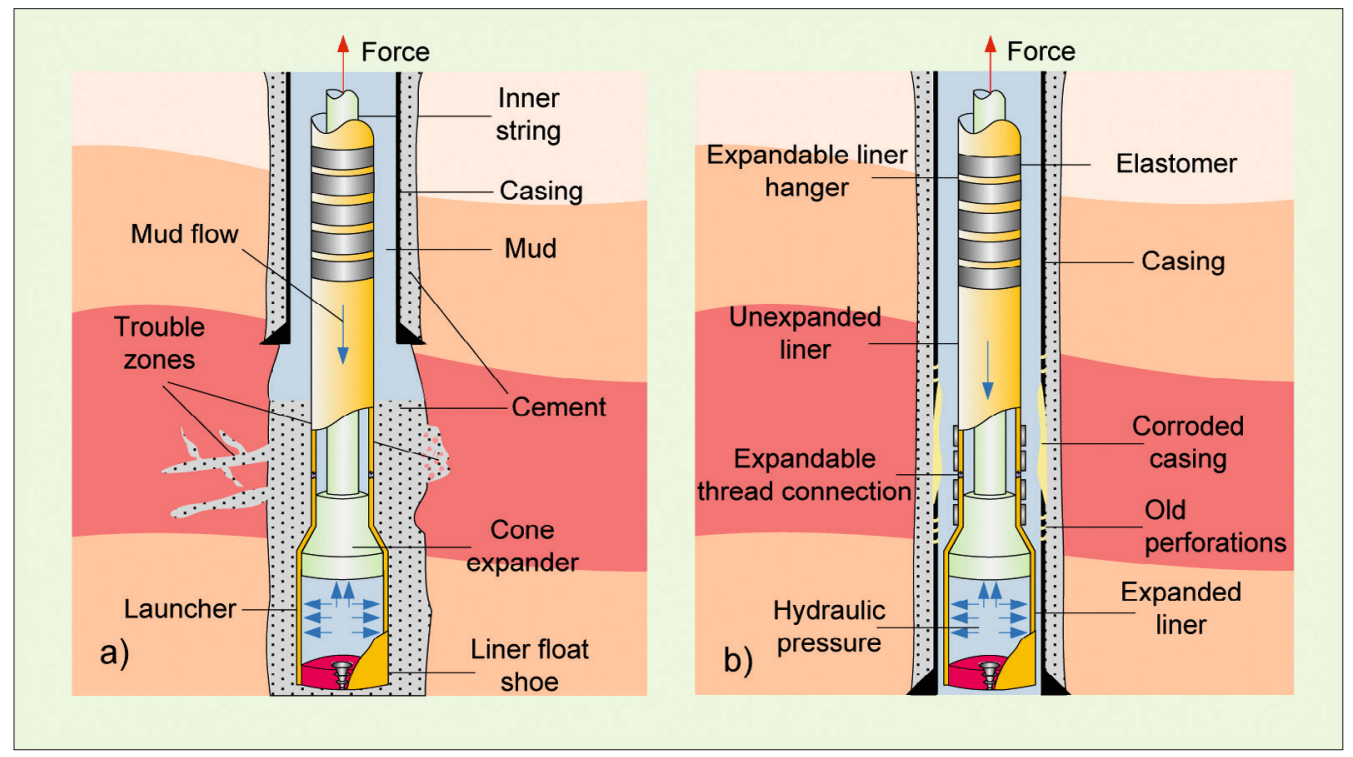

Figure 3: The process of expanding the open hole liner (a) and the cased-hole liner (b)

vez, 2013), expansion cone/mandrel (Park et al., 2015) or expansion cone (Benzie et al., 2018; Dell et al., 2019). The name cone expander is used in this paper.

The expansion assembly as well as the float assembly are in the chamber (housing) known as the launcher, which is placed at the bottom of the expandable liner. The launcher is constructed of thin-walled, high-strength steel. The outside diameter (OD) of the launcher is the same or less than the drift of the previous casing, and the thickness of its wall is less than that of the expandable liner (Dell et al., 2019).

The upward movement of the cone expander, which is connected to the inner string, through the expandable liner is achieved hydraulically (by the action of the hydraulic pressure on the cone expander itself) and/or mechanically (by pulling the inner string upwards). The hydraulic pressure on the cone expander is applied by pumping mud through the inner string. During the expansion process, the enlargement of the pipe diameter causes the overall pipe length to shorten from the top as a result of material balance. As the liner is expanded, its outer diameter (OD) increases significantly, while the wall thickness decreases only slightly. In this way, the greatest possible values of post-expansion burst and collapse are preserved. Depending on the pipe diameter, it is possible to achieve an expansion of over $25 \%$, based on the ID of the pipe. However, most applications use $88.9 \mathrm{~mm}$ to $406.4 \mathrm{~mm} \mathrm{(31/2}$ in. to $16 \mathrm{in}$.) expandable liners and require less than a 20\% expansion (Filippov et al., 1999; Dell et al., 2019). A typical expansion rate for solid expandable tubulars is approximately $2.4 \mathrm{~m} / \mathrm{min}$ $(7.8 \mathrm{ft} / \mathrm{min})$ (Fanguy et al., 2004).

The propagation forces required to expand the liner depend on the liner's size and mechanical properties and can reach for example $1,330 \mathrm{kN}\left(300,000 \mathrm{lb}_{\mathrm{f}}\right)$ when expanding $339.7 \mathrm{~mm}\left(13 \frac{3}{8} \mathrm{in}\right.$.) casing (Dell et al., 2019).
The process of expanding the open-hole (a) and the cased-hole liner (b) from bottom to top is shown in Figure 3. It is also possible to push the cone downward, using hydraulic pressure and/or push force, to expand the liner from top to bottom. In this case, the expansion of the open hole liner will result in its shortening from the bottom to the top, so the expanded liner may not cover an adequate interval at the bottom of the hole (Dell et al., 2019).

\subsection{Scope of solid expandable tubulars}

Solid expandable tubulars (SET) have a wide application in the petroleum engineering and enable the solution of various problems encountered during the drilling process, well completion and workover or production (see Table 1). Initially, three expandable tubular products (OHL, CHL and ELH) have been identified and developed by Enventure Global Technology for commercialization. Later, other SET products were developed, so today this company is the world's leading provider of $\mathrm{SET}^{\circledR}$ and $\mathrm{ESeal}^{\mathrm{TM}}$ solid expandable technology solutions for the energy industry. These systems are used in openhole and cased-hole environments to mitigate trouble zones, add casing points, remediate damaged casing, and cover perforations. SETs have built a reputation of being an enabling technology with over 600 installations in the first seven years (Heathman et al., 2007).

Besides EnventureGT, some other companies, such as Weatherford and Halliburton also provide SET products. Weatherford's MetalSkin technology has been used extensively to address wellbore isolation challenges. In 2002, Weatherford deployed its solid expandable liner hanger system for the first time (in Asia), and its MetalSkin cased-hole remediation system (in California) (ULR 9). 
Table 1: Solid expandable products and the area of their application

\begin{tabular}{|c|c|c|}
\hline $\begin{array}{l}\text { Solid Expandable } \\
\text { Product }\end{array}$ & Area of application/Benefits & $\begin{array}{l}\text { Examples of commercial } \\
\text { products (name/company) }\end{array}$ \\
\hline $\begin{array}{l}\text { Expandable } \\
\text { Openhole Liner } \\
\text { (OHL) } \\
\text { (Filippov et al., 1999; } \\
\text { Grant and Bullock, } \\
\text { 2005; Shaikh et al., } \\
\text { 2013; Cameron et al., } \\
\text { 2013; Park et al., } \\
\text { 2015; Aidoo et al., } \\
\text { 2016; Benzie, et al., } \\
\text { 2018; Zhu et al., 2020) }\end{array}$ & $\begin{array}{l}\text { - Mitigate mud loss and/or solve lost-circulation problems. } \\
\text { - Seal off trouble zones, such as shallow water flows and subsalt } \\
\text { rubble zones. } \\
\text { - Isolate high-pressure zone. } \\
\text { - Preventively mitigate risk in exploratory drilling. } \\
\text { - Replace a conventional drilling liner and provide a larger ID. } \\
\text { - Provide an additional casing string while conserving hole size. } \\
\text { - Slim down the entire wellbore. } \\
\text { - Preserve completion size in challenging drilling applications. } \\
\text { - Extend reach. } \\
\text { - Reach reservoirs with larger casing to increase production. } \\
\text { - Maximize recovery in side-tracking operations. } \\
\text { - Reach the reservoir faster and more economically. }\end{array}$ & $\begin{array}{l}\text { SET }{ }^{\circledR} \text { Openhole Liner system/ } \\
\text { EnventureGT (ULR 2) } \\
\text { SameDrift Openhole Liner } \\
\text { (provide the same drift as the } \\
\text { casing string above the } \\
\text { expanded liner)/EnventureGT } \\
\text { (ULR 3). } \\
\text { MetalSkin }{ }^{\circledR} \text { openhole liner/ } \\
\text { Weatherford (ULR 4). }\end{array}$ \\
\hline $\begin{array}{l}\text { Expandable Cased- } \\
\text { Hole Liner (CHL) } \\
\text { (Filippov et al., 1999; } \\
\text { Bargawi et al., 2005; } \\
\text { Cameron et al., 2013; } \\
\text { Benzi et al., 2018) }\end{array}$ & $\begin{array}{l}\text { - Repair long corroded casing intervals. } \\
\text { - Isolate/repair existing damaged or worn casing. } \\
\text { - Seal off unwanted (or old) perforations. } \\
\text { - Provide permanent casing repair with minimal inside-diameter } \\
\text { (ID) restriction. } \\
\text { - Reinforce casing to enable stimulation treatments, wellbore } \\
\text { treatments, and hydraulic fracturing operations. }\end{array}$ & $\begin{array}{l}\text { ESeal }^{\mathrm{TM}} \text { Liner/ EnventureGT } \\
\text { (ULR 5). } \\
\text { MetalSkin cased-hole liner/ } \\
\text { Weatherford (ULR 6). }\end{array}$ \\
\hline $\begin{array}{l}\text { Expandable Liner } \\
\text { Hanger (ELH) } \\
\text { (Filippov et al., 1999; } \\
\text { Hayward et al., 2014) }\end{array}$ & $\begin{array}{l}\text { - Reduce risks associated with liner deployment, setting and } \\
\text { sealing. } \\
\text { - Eliminate potential leak paths and create a leak free liner hanger. } \\
\text { - Work in a variety of cemented and non-cemented applications. } \\
\text { - Hold in tension and compression during the life of the well. } \\
\text { - Set in deviated wellbores. } \\
\text { - Reduce operating steps. }\end{array}$ & $\begin{array}{l}\text { Expandable Liner } \\
\text { Hanger (ELH) System/ } \\
\text { EnventureGT } \\
\text { VersaFlex® expandable liner } \\
\text { hanger (ELH) system / } \\
\text { Halliburton (ULR 7) } \\
\text { VersaFlex@ GT expandable } \\
\text { liner hanger (ELH) system/ } \\
\text { Halliburton (ULR 7) }\end{array}$ \\
\hline $\begin{array}{l}\text { Open } \\
\text { (Gran } \\
\text { 2005) }\end{array}$ & tion. & $\begin{array}{l}\text { Openhole Clad (ОНСТ) } \\
\text { System/ Enventure GT }\end{array}$ \\
\hline $\begin{array}{l}\text { Internal Casing } \\
\text { Patch } \\
\text { (Wright et al., 2003; } \\
\text { Cameron et al., 2013; } \\
\text { Tao, 2015) }\end{array}$ & $\begin{array}{l}\text { - Restore tubular integrity with a permanent steel seal in } \\
\text { production, disposal storage, and injection wells. } \\
\text { - Repair collar and casing leaks, unwanted perforations, and worn } \\
\text { casing with minimal ID restrictions } \\
\text { - Provide a permanent repair for short- and medium-length tubing } \\
\text { or casing intervals. } \\
\text { - Provide long-lasting alternative to temporary cement squeezes. } \\
\text { - Isolate open frac sleeves to enable fracturing below patch. }\end{array}$ & $\begin{array}{l}\text { FlexClad }{ }^{\text {TM }} \text { System/Enventure } \\
\text { GT } \\
\text { HOMCO casing patches/ } \\
\text { Weatherford (ULR 8) } \\
\text { Note: To date, over } 12,000 \\
\text { Weatherford's HOMCO casing } \\
\text { patches have been installed } \\
\text { worldwide (ULR 8). }\end{array}$ \\
\hline $\begin{array}{l}\text { Slotted Expandable } \\
\text { Liner } \\
\text { (Mason et al., 2011) }\end{array}$ & $\begin{array}{l}\text { - Multizone Openhole Frac-Packs. } \\
\text { - Expand against the formation wall to eliminate the requirement } \\
\text { for perforating. } \\
\text { - Applicable where downhole sand control is not required. }\end{array}$ & $\begin{array}{l}\text { Slotted expandable } \\
\text { completion liner (ECLTM)/ } \\
\text { Weatherford (ULR 9) }\end{array}$ \\
\hline $\begin{array}{l}\text { ble } \\
\text { ons }\end{array}$ & $\begin{array}{l}\text { - Threaded connections in solid expandable liners are designed to } \\
\text { have better strength and sealing properties than their } \\
\text { conventional equivalents - before, during, and after expansion. }\end{array}$ & - \\
\hline $\begin{array}{l}\text { Expandable sand } \\
\text { screen } \\
\text { (ULR 9; ULR 10) }\end{array}$ & $\begin{array}{l}\text { - Cost-effectively maximize production. } \\
\text { - Minimize sand infiltration. } \\
\text { - Eliminate or reduce openhole/screen annulus. } \\
\text { - Stabilize the formation, reduce the completion skin, and } \\
\text { minimize frictional pressure losses. } \\
\text { - Improve the range of remedial options over traditional gravel } \\
\text { pack. }\end{array}$ & $\begin{array}{l}\text { ESS }{ }^{\circledR} \text { expandable sand } \\
\text { screens/ Weatherford (ULR 9) } \\
\text { PoroFlex } ® \text { Expandable } \\
\text { Screen/ Halliburton (ULR 10) }\end{array}$ \\
\hline
\end{tabular}




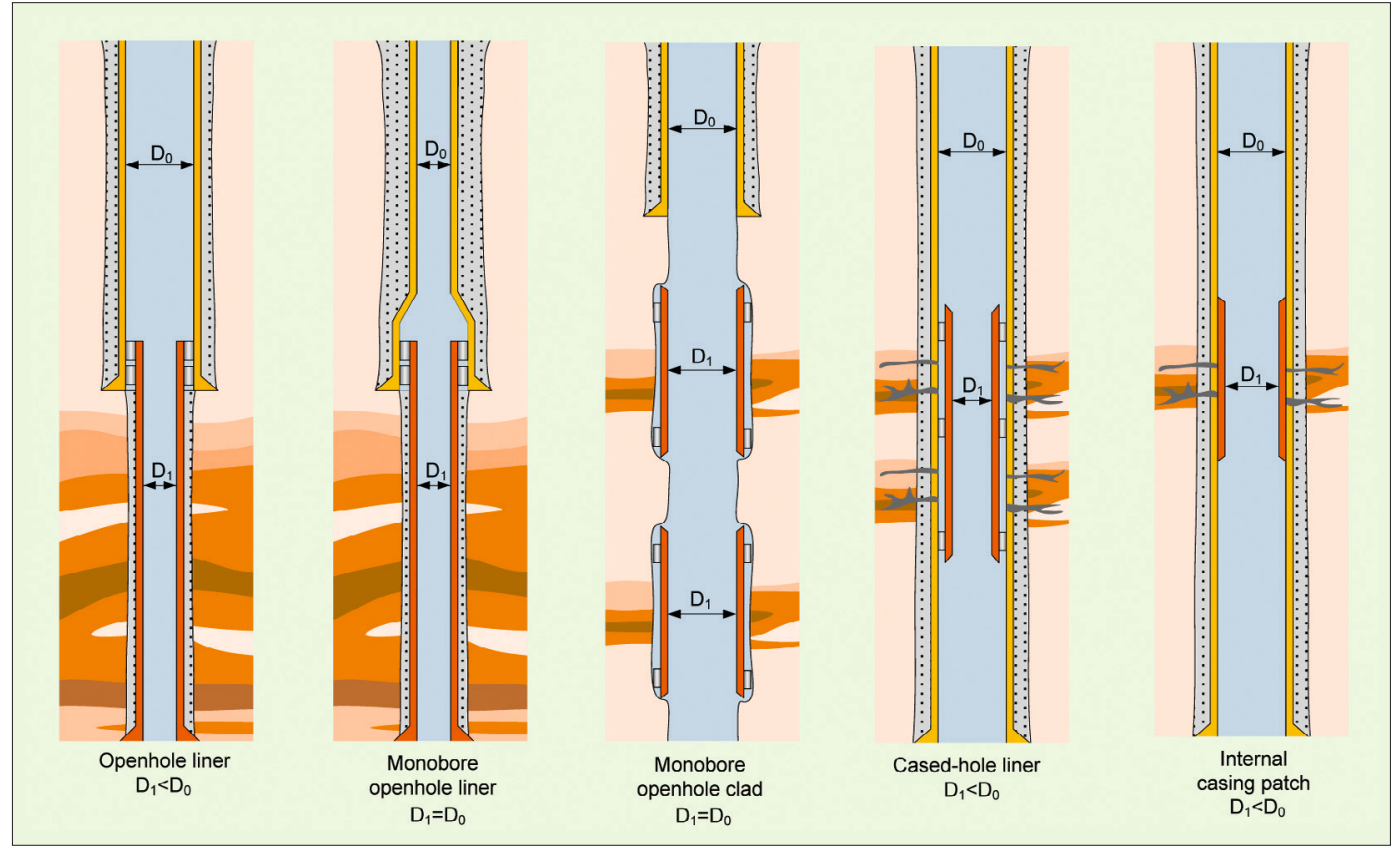

Figure 4: Possible applications of expandable liner, clad and patch (modified according to Stringer and Farley, 2013)

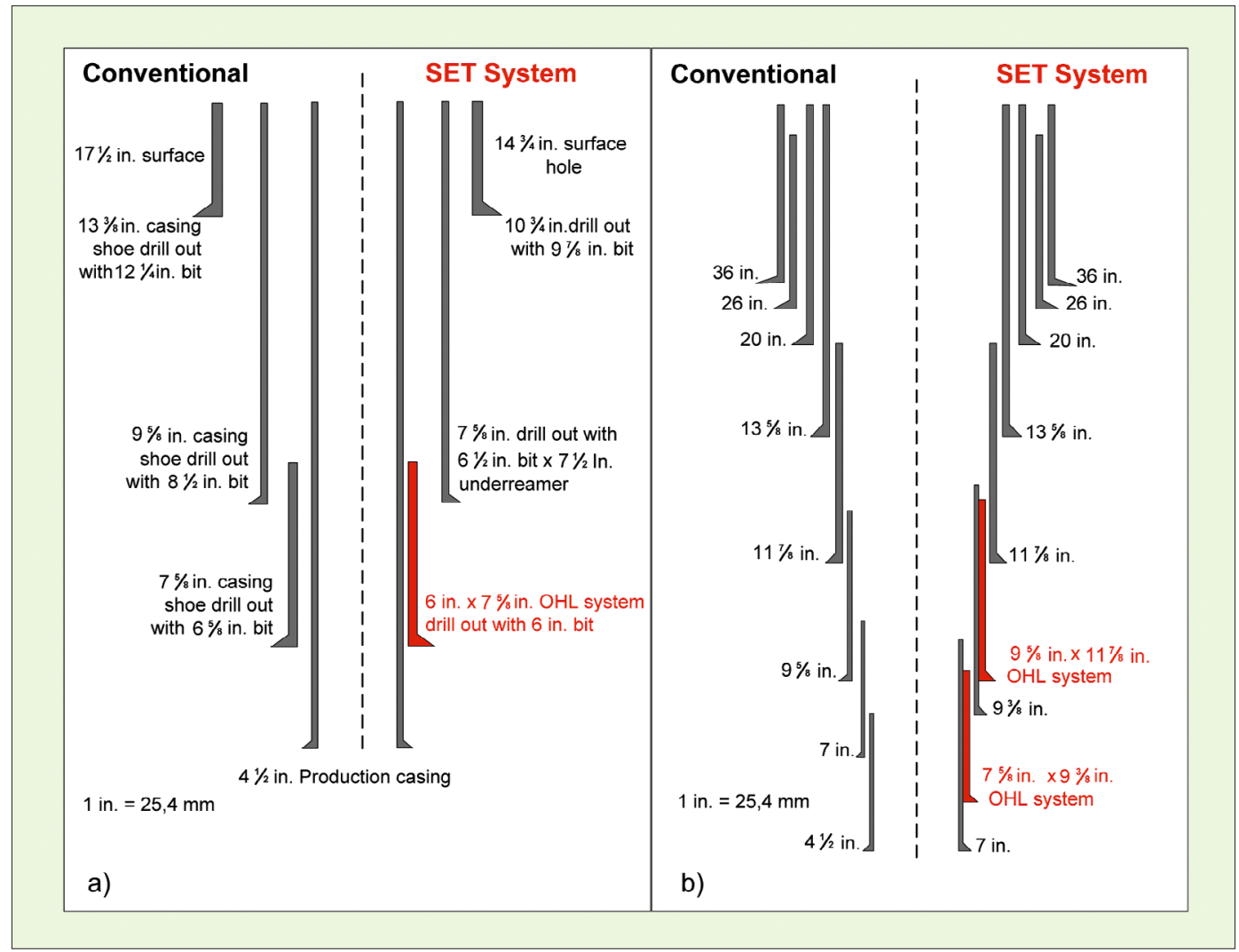

Figure 5: SET system enables a slim-well design (a) and running of additional OHLs to isolate trouble zones $(\mathrm{b})$

Possible ways of applying solid expandable tubulars (liner, clad and patch) and the ratio of the inner diameter of the previous casing $\left(\mathrm{D}_{0}\right)$ to the inner diameter of the expandable tubular $\left(D_{1}\right)$ are shown in Figure 4.
It can be concluded that the inner diameter of the installed monobore open hole liner and clad is the same as the inner diameter of the previous casing and that in the case of openhole liner, cased-hole liner and internal cas- 


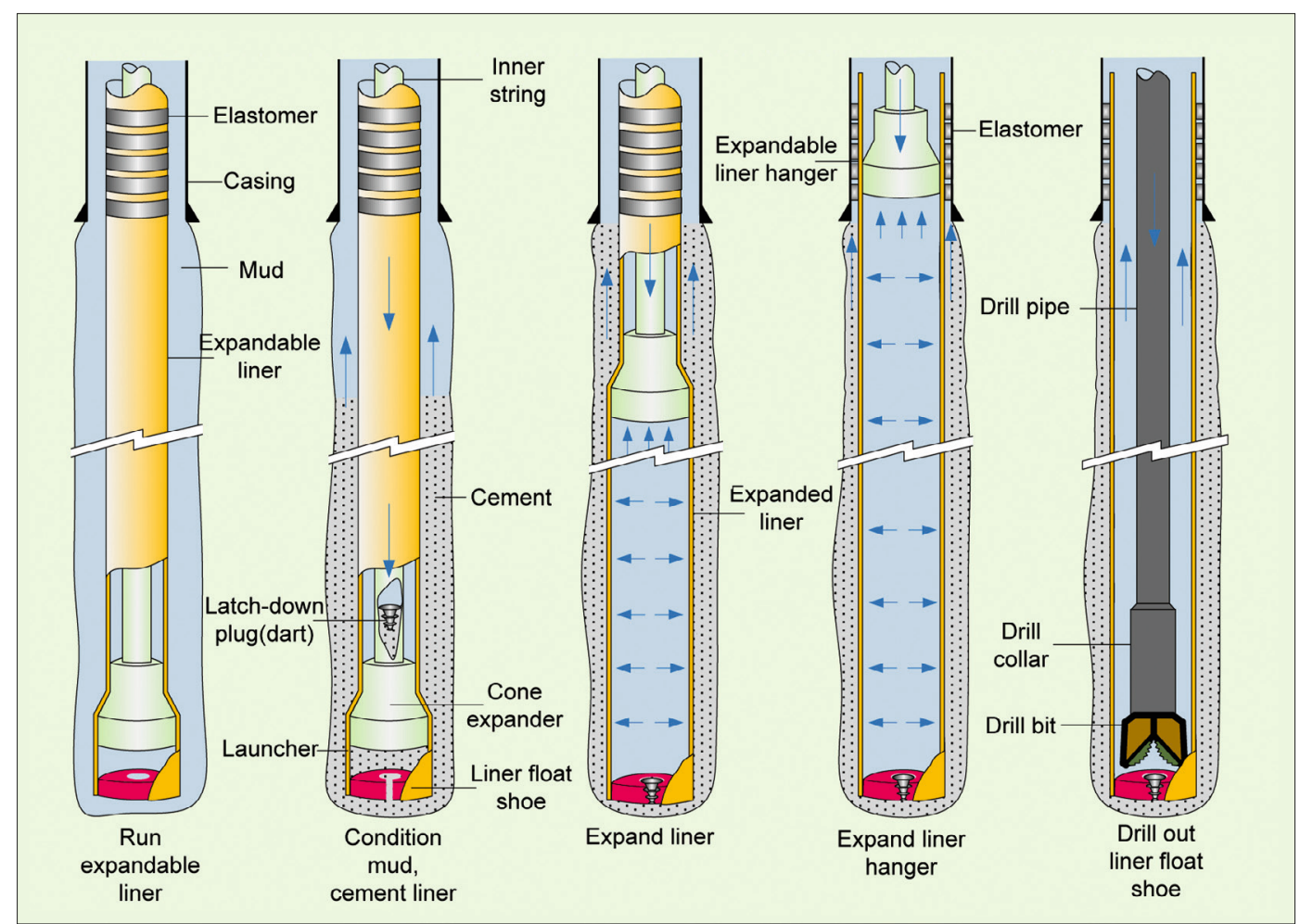

Figure 6: Running and expansion process of expandable open hole liner system (modified according to Brunner, 2002)

ing patch the inner diameter is slightly smaller than the inner diameter of the previous casing (Tao, 2015). To mitigate drilling hazards, operators in Norway, Oman, the Black Sea, Turkey, Australia, Saudi Arabia, and Azerbaijan have successfully incorporated monobore open hole liners in the well design, enabling overcoming hazards and achieving well objectives (Stringer and Farley, 2013). Petroleum Development Oman LLC (PDO) installed a 29-m section of expandable openhole liner in the Fahud-335 well, $276 \mathrm{~m}$ below the $244.47 \mathrm{~mm}$ ( $95 \%$ in.) casing shoe, selectively isolating a problematic shale interval.

A comparison of conventional well design and slimwell design that includes OHL, as well as the running of additional OHL to isolate trouble zones, is shown in Figure 5.

\section{Running and expansion process of expandable solid liner systems}

Expandable tubular technology must be considered as a complete system as each expandable product has been developed as a system that includes application-specific hardware required, accessories, hardware installation services, and an expert team (Bybee, 2000). For the drilling process, the three most important expandable products are: Expandable Openhole Liner (OHL), Expandable Cased-Hole Liner (CHL) and Expandable Liner Hanger (ELH), so they will be discussed in more detail below.

\subsection{Expandable Openhole Liner}

The expandable openhole liner allows the operator to increase the casing length with negligible reduction in diameter and to extend conventional casing programs in exploratory wells to reach promising zones that are deeper than expected. The diameter of the OHL at the total depth is larger than the otherwise possible when using a conventional casing program and allows the installation of production equipment, and thus the conversion of an exploration well into a production well.

The expandable openhole liner can be a useful, effective, and cost saving solution in operations where very large casing programs in the upper hole section are cost prohibitive. In addition to the above, OHL can be installed to cover lost-circulation or shallow water-flow zones in deepwater and subsalt environments. In older fields undergoing redevelopment, the expandable openhole liner can help reach deeper reserves and can isolate water zones that have penetrated horizontal re-entry wells (Bybee, 2000). Liner length is weight dependent and is calculated at the time of design (ULR 2). Running and expansion process of expandable openhole liner system takes place in several stages (Dupal et al., 2001; Brunner, 2002; Benzi, 2003; Kupresan 2014; Dell et al., 2019).

To install the OHL, it is first necessary to drill a section of the hole larger in diameter than the diameter of the previously installed casing or liner. The extra space allows for a good cement job around the expanded liner. 


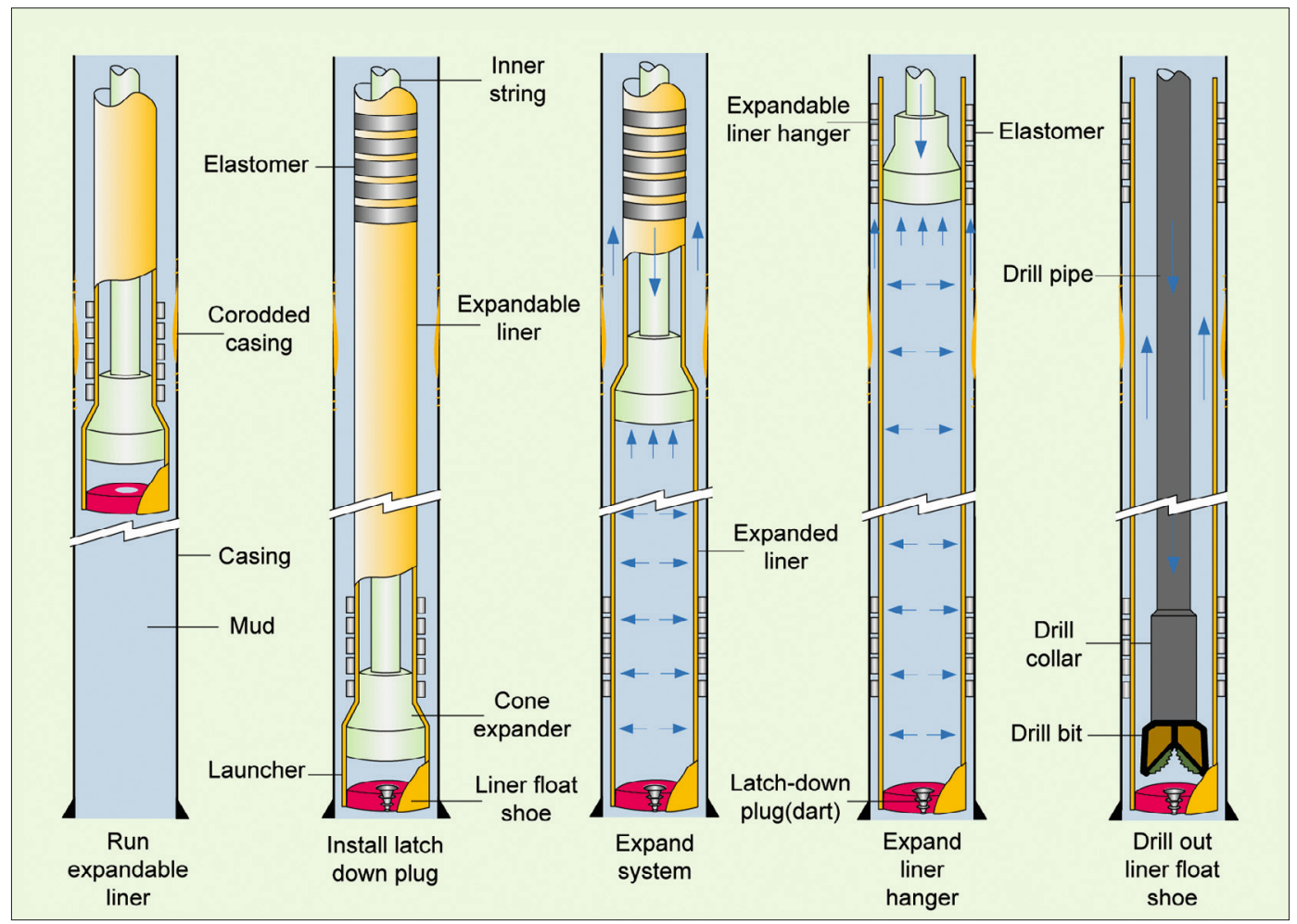

Figure 7: Running and expansion process of expandable cased hole liner system (modified according to Dell et al., 2019)

Once the open hole section is drilled, the inner string (also called a work-string or drill pipe work string) is run with an expandable open hole liner, expansion assembly and a launcher (shoe assembly) (see Figure 6).

After the expandable liner is run into the hole to the setting depth and anchored in the previous casing at its lowest depth (shortening of the liner occurs in the overlap), the circulation of the mud is established for its conditioning, followed by the pumping of a suitably designed cement slurry through the inner string, cone expander and liner float shoe. Anchoring is achieved by expanding the anchor hanger joints (expandable liner joints with bonded elastomeric bands) inside the previous casing. Once the open hole liner is cemented, after pumping the calculated volume of the cement slurry, the latch-down plug (displacement dart) is launched down the inner string to facilitate liner expansion. The dart pumped by the displacement fluid pushes the cement slurry out of the liner and finally lands in the liner float shoe, seals off the float equipment, and creates a pressure chamber. The expansion assembly is then pressurized using the surface pumping unit up to $10.34-13.79$ MPa (1,500 - 3,000 psi) (depending on system size) (Drilling contractor, 2001). The hydraulic pressure blows out burst disks in the sub-assembly, transmitting pressure to the base of the cone expander. The pressure drives the cone expander up the expandable liner, causing the OHL to expand. The inner string rises with the cone expander out of the hole. When the expansion process enters the previous casing string, the expandable liner hanger expands, and the elastomer clads the two pipes together. This seal typically forms a mechanical connection with a $305 \mathrm{kN} / \mathrm{m}(225,000 \mathrm{lb} / \mathrm{ft})$ pullout strength (Drilling contractor, 2001). After the liner and liner hanger are expanded, a drill string is run, and an expandable liner float shoe is drilled. The material to be drilled out is made of aluminum and composite material. Drill out time can range from $<1$ hour to 6 hours based on the type of bit utilized, rotation speeds, and weight on bit (ULR 1).

After expansion, the outside diameter (OD) of the expanded liner is greater than the outside diameter of the launcher, while the internal diameter (ID) of the liner expands to the same internal diameter of the launcher.

\subsection{Expandable Cased-Hole Liner System (CHL)}

Production from older fields can still be cost-effective if expandable case hole liners are installed without the use of new production liners that significantly reduce cross-sectional flow areas and production.

Expandable cased-hole liner can be used: (a) for remediation work in older or damaged wells to repair over several hundred meters of existing damaged or worn casing with minimal casing-inner diameter (ID) reduction; (b) for well conditions where a very long corroded interval needs to be repaired for current production, side-tracking, or for deepening, and (c) to seal off perforations, that cannot be sealed off using a cement squeeze job, for recompletion or allowing existing wellbores to 
be used to drill to new horizons (Filippov et al., 1999. Bybee, 2000).

The elastomer-wrapped hanger joints are located at both the top and the bottom of the expandable casedhole liner to enhance the hydraulic integrity of the liner. This elastomer fills the voids between the perfectly circular expanded liner and the existing casing, which is usually not perfectly circular. The mechanical pullout strength is approximately $189.7 \mathrm{kN} / \mathrm{m}(13,000 \mathrm{lb} / \mathrm{ft})$ without an elastomer and $305 \mathrm{kN} / \mathrm{m}(225,000 \mathrm{lb} / \mathrm{ft})$ with an elastomer (Filippov et al., 1999).

To install CHL, the bit and the scraper assembly should first be run to clean the existing casing of scale and corrosion. The integrity, inside diameter, wall thickness and ovality of the previous casing should then be determined. Then begins the running of the CHL, similar to the running of the OHL (see Figure 7).

Once the expandable cased-hole liner has been run into the hole and positioned, the latch-down plug (displacement dart) is pumped to facilitate liner expansion. The expansion assembly is then pressurized, the liner expansion process begins from the bottom to up and ends with the expansion of the liner hanger. This is followed by a pressure test of the expanded liner. At the end of the process, the liner float shoe is drilled out.

\section{Cementing expandable open hole liner}

In general, good cementing practices include the four main issues: well conditioning, pipe centralization, mud removal and cement slurry design (Rahman and Zulkafly, 2004). An expandable open hole liner can be cemented in place like conventional liner (Heathman et al., 2007). However, in the case of cementing an expandable liner, certain limitations and specifics need to be considered.

Cementing expandable liners includes the challenges of achieving zonal isolation without the use of pipe movement or pipe centralization, which increases the probability for cement slurry channelling. If possible, the use of ceramic centralizers is recommended to minimize channelling and achieve adequate centralization of the liner.

The adequate cementation of an open hole expandable liner is essential for long-term liner integrity, especially under high-pressure (HP)/high-temperature (HT) conditions, because there is no possibility for a remedial cement job (Bhaisora et al., 2015).

To install an expandable system, it is necessary to drill an over-gauge hole. The extra space allows for a good cement job around the expanded casing. An inner string (usually drill pipe) is run through the assembly to avoid contamination of the cement slurry by other fluids while cementing. After the string is run, an inner-string cement job is performed with a specially designed cement slurry. The amount of cement slurry is calculated and then pumped so that the top of the cement slurry is about $50 \%$ of the liner length before expansion (ULR1).
As expansion occurs, the cement slurry fills the remaining annulus. Typically, the cement slurry is pumped into the inner string at a low pumping rate, which does not facilitate mud removal.

In addition to pumping the cement slurry through the inner string before the expansion of the liner, it is also possible to inject it after the expansion as a simple shoe squeeze, which is a more desirable method for short installations (Heathman et al., 2007). In this case, operators rely on planned squeezes to establish shoe integrity before drilling ahead. This method of liner cementation can greatly increase the cost of installing an expandable openhole liner.

Experience with cementing expandable casing has now developed to the point that it has become possible to write best practices for achieving zone isolation $(\mathbf{O w}-$ oeye et al., 2002; Sanders et al., 2003; Rahman and Zulkafly, 2004; Fanguy et al. 2004; Morris et al., 2004; Merritt, 2005; Morrison et al., 2005; Heathman et al., 2007; Schultz et al., 2008; Hayward, et al., 2014; Bhaisora et al., 2015).

These best practices include not only conventional methods like hole conditioning, but also novel means such as the incorporation of settable spotting fluids (SSFs), specialized extended-set cements, non-Portland cements, (Owoeye et al., 2002), gas-block cement (Morrison et al., 2005), off bottom cementing (OBC) system technology including a diverter (DV) tool (Hayward, et al., 2014), a properly designed spacer system, specialized tail and lead cement slurries based on combining chemical and physical solutions to obtain the goal of expansion without a premature set of the cement, and modification of standard API laboratory cement slurry testing procedures, especially for HPHT conditions (Bhaisora et al., 2015) and cementing of the long open hole expandable liners (Schultz et al, 2008). In OHL, cementing operators use a premixed cement slurry/liquid cement premix (LCP) or mix cement slurry on the fly on a cement-mixing unit, which is a widely accepted industry practice. The LCP slurry is prepared in a mixing facility prior to transport to the well site (Rae and Johnston, 1996; Fanguy et al., 2004). Bulk additives used in the cement slurry are dry blended into the cement at the bulk plant and the blended material is transported to the rig site using bulk transport equipment. Liquid additives are added into the slurry mix water. The alternative approach to mixing on the fly is to batch mix the cement slurry (Merritt, 2005; Rahman and Zulkafly, 2004; Bhaisora et al., 2015). Batch mixing, where logistically feasible, no matter the cost, should be preferred because it allows better control of the cementing operation and more efficient risk management.

\subsection{Cement slurry design}

When designing a cement slurry, a whole range of input data are considered, such as expandable liner size, planned setting depth, liner length, hole size (under- 
reamed), openhole caliper volume (to calculate volume of the cement slurry), drilling fluid weight and type, planned top of cement (TOC), bottomhole static temperature (BHST)/ bottomhole circulating temperature (BHCT) and calculated liner expansion time.

Cement slurry design for expandable open hole liner cementation differs to some extent from the conventional design in that the cement slurry must have a sufficiently long fluidity (pumpability) time, which depends on the time required for the expansion of the liner (Heathman et al., 2007; Schultz et al., 2008). The calculation of the actual cement slurry volume is based on the openhole caliper volume considering the post-expansion outside diameter of the open hole expandable liner.

Due to the long expansion time of the liner, special attention should be paid to the stability of the cement slurry under downhole conditions and its properties including thickening time, a long zero gel time, short transition time and delayed initial strength development.

\subsubsection{Rheological properties}

A cement slurry should have the required rheological properties that will allow it to flow through the narrow part of the annulus around the expandable liner. A cement slurry should have a plastic viscosity (PV) of less than $0.1 \mathrm{~Pa} \cdot \mathrm{s}(100 \mathrm{cP})$ and a yield strength (YP) of less than $14.37 \mathrm{~Pa}\left(30 \mathrm{lb}_{\mathrm{f}} / 100 \mathrm{ft}^{2}\right)$ (Rahman and Zulkafly, 2004). A cement slurry better displaces mud from the annulus if it has higher values of PV and YP than mud, with the difference in YP having a more pronounced effect. It is therefore recommended that, whenever possible, the YP of the cement slurry be at least $4.79 \mathrm{~Pa}\left(10 \mathrm{lb}_{\mathrm{f}}\right.$ $/ 100 \mathrm{ft}^{2}$ ) greater than the YP of the mud. This difference results in a more flattened profile of the cement slurry velocities and enhances the displacement of the mud towards the surface, even when the standoff of the liner in the channel is only $46 \%$ (Silva et al., 1996).

\subsubsection{Cement slurry density}

The required density of the cement slurry can be adjusted according to the conditions in the well by adding suitable light-weight materials (extenders) (e.g. bentonite, expanded perlite, gilsonite, fly ash, microspheres, diatomaceous earth, sodium silicate and others) to prevent circulation losses when a weak formation with low fracture gradient is present, or weighting agents for densities greater than $2000 \mathrm{~kg} / \mathrm{m}^{3}$ (e.g. barite, hematite, ilmenite, $\mathrm{Mn}_{3} \mathrm{O}_{4}$ ). In any case, it is necessary to determine the equivalent circulation density (ECD), which must always be within the limits of the safety margin to avoid fracture of the surrounding rocks and loss of cement slurry in them (Gaurina-Međimurec et al., 2021).

\subsubsection{Free water and settling}

Free water is any water in the cement slurry that is more than what is required to fully hydrate Portland ce- ment and other additives. It can physically separate as a cement slurry sets and is therefore undesirable since channels tend to form through the set cement, providing potential gas migration paths. A cement slurry must have zero free water during a two-hour static test measuring at $45^{\circ}$ and $90^{\circ}$ angles, and there should be no settling of particles from the cement slurry to prevent the formation of a layer of water on top of the slurry, and a difference in density along the column of the cement slurry (Heathman et al., 2007).

\subsubsection{Thickening time}

The thickening time of a cement slurry presents the time during which a cement slurry remains in a fluid state and is capable of being pumped. Thickening time is assessed under simulated downhole conditions in compliance with API standards using a consistometer (atmospheric consistometer or HPHT (high-pressure/hightemperature) consistometer) that plots the consistency of a cement slurry over time at the anticipated temperature and pressure conditions. The end of the thickening time is considered to be 50 or $70 \mathrm{Bc}$ for most applications. When the slurry reaches a consistency of $70 \mathrm{Bc}$, it is considered unpumpable in the well. In the case of a conventional casing or liner cementation, the thickening time encompasses mixing and pumping time, displacement time, plug release time and a safety factor (usually 30 - 60 minutes are used).

Determination of the thickening time in the laboratory should be carried out using a HPHT consistometer and by simulating the actual conditions of cementation (Bottom Hole Circulating Temperature-BHCT and actual bottomhole pressure-BHP). Suitable retarders (e.g. lignosulfonates, cellulose derivatives, hydroxycarboxylic acids, organophosphates, synthetic retarders, inorganic compounds, salt, and others) are added to the cement slurry to prolong the thickening time.

In the case of cementing an expandable open hole liner, a longer thickening time is required because the cement slurry must be fluid during the liner expansion process and is often referred to as fluidity time.

\subsubsection{Fluidity time}

Fluidity time is defined as the time the static gel strength is below $48 \mathrm{~Pa}\left(100 \mathrm{lb}_{\mathrm{f}} / 100 \mathrm{ft}^{2}\right)$ (Rahman and Zulkafly, 2004). This time is generally taken to be about twice the time for the actual operations to allow corrective actions in case of any operational problems (Rahman and Zulkafly, 2004).

The required thickening or fluidity time is calculated by summing the cement slurry mixing time, pumping and displacement time, static period to rig down the cement head and start the expansion procedure, liner expansion time plus a safety factor of 2 hours. Typically, a 10 to 12 hour fluidity time is required to allow sufficient time for the expansion operation and for the retrieval of 


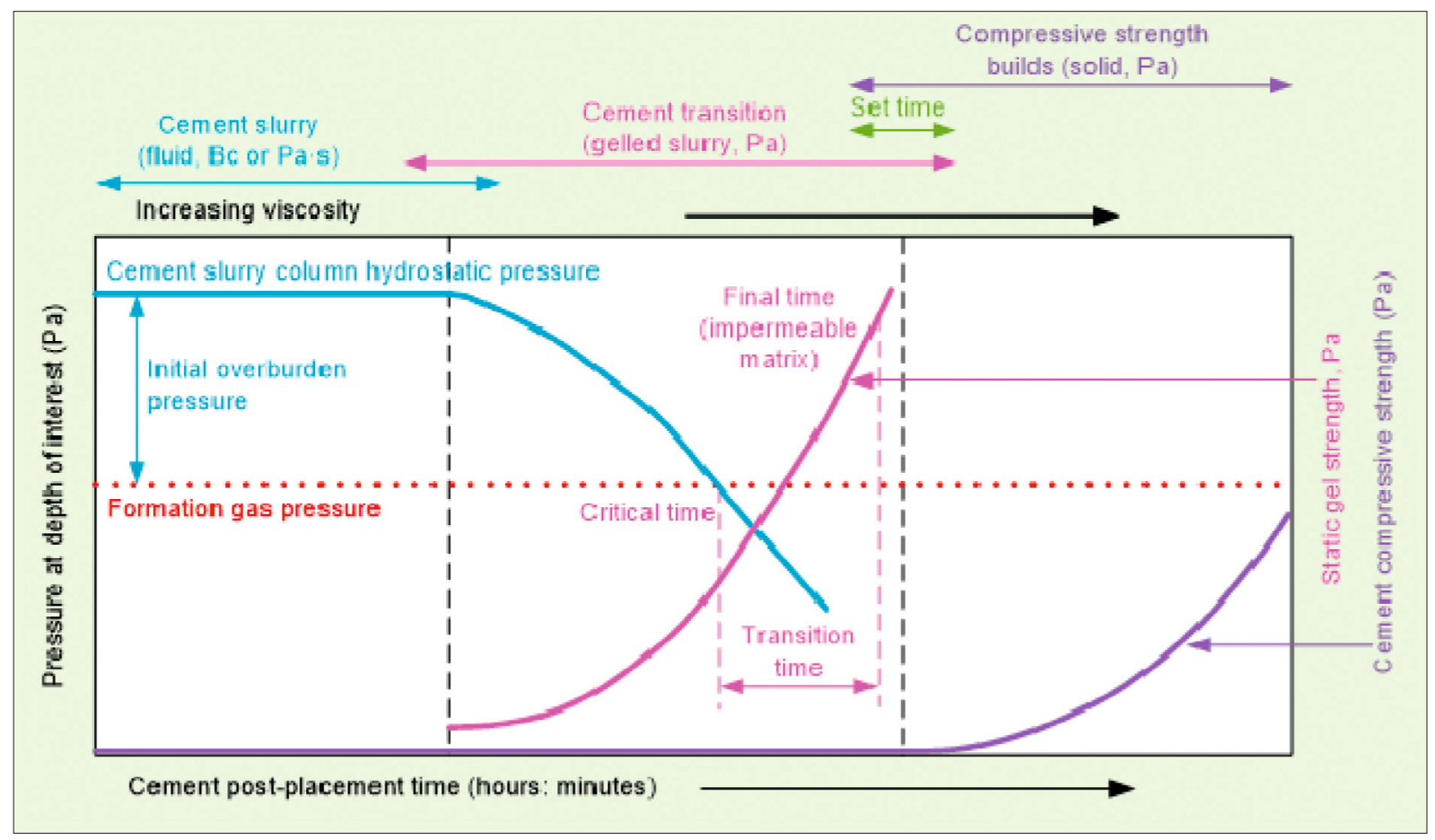

Figure 8: Development of static gel strength of the cement slurry after its pumping into the annulus and cement compressive strength (modified according to Li et al., 2016)

the expansion assembly. However, depending on the project, the required fluidity time of the cement slurry can be, for example, from 7 hours (Fanguy et al., 2004) up to as much as 17 hours (Bhaisora et al., 2015).

Determination of the fluidity time in the laboratory should be carried out by simulating the actual conditions of cementation and the liner expansion schedule. Laboratory testing consists of starting and stopping the motor that turns the slurry cup in the consistometer. Determining the duration of the cycles is based on the expansion time of each joint of liner, which coincides with the cement slurry static time and dynamic movement based on pipe expansion downhole. Therefore, each cycle consists of an ON/OFF schedule for the specific case. For the conditions described in the paper written by Schultz et al. (2008), the cycle duration is 4 minutes on and 6 minutes off. The fluidity time of the cement slurry is increased by the addition of cement retarders.

\subsubsection{Static Gel Strength (SGS)}

The static gel strength of the cement slurry after its pumping into the annular space is essential for successful cementation of expandable pipes. The gelling of the cement slurry after pumping into the annular space takes place due to the mutual attraction of the particles present in it (Fanguy et al., 2004). During the expansion of the liner, a highly gelled cement slurry can cause its loss into the surrounding rocks. Instead of the level of cement slurry in the annular space rising during liner expansion, it can remain at the same level as it was before the pipe expansion because the highly gelled cement slurry is predominantly forced into the formation, and so parts of the liner remain uncemented (Rahman and Zulkafly, 2004). Reducing the mutual attraction of particles reduces the gelling of the cement slurry and thus reducing the likelihood of voids and channels in the set cement that can jeopardize the effectiveness of zonal isolation, the most important task of any cementation. The development of the cement slurry static gel strength after its pumping into the annulus takes place through two periods. The first is a period in which the slurry is completely fluid and the value of the gel strength is small (long zero gel time), and the second is a transition period which should generally be shorter than 45 minutes to avoid gas migration through a cemented annulus (Bhaisora et al., 2015). Before early gelation, the hydrostatic pressure will overcome the formation gas pressure and prevent gas migration (see Figure 8).

Gas can migrate into the cemented annulus of a wellbore during early gelation when hydrostatic pressure within the cement slurry drops below the formation gas pressure (critical time). If the cement slurry has not developed sufficient strength to withstand the gas pressure, gas will invade the hydrating cement slurry and create gas channels until the cement slurry develops sufficient cohesive strength (final time) to prevent the entry and migration of gas or other formation fluids.

The period between critical time and final time is defined as the transition time. Therefore, the transition period should be as short as possible to minimize the risk of gas migration. Static gel strength reflects resistance development within a cement slurry but is not sufficient 


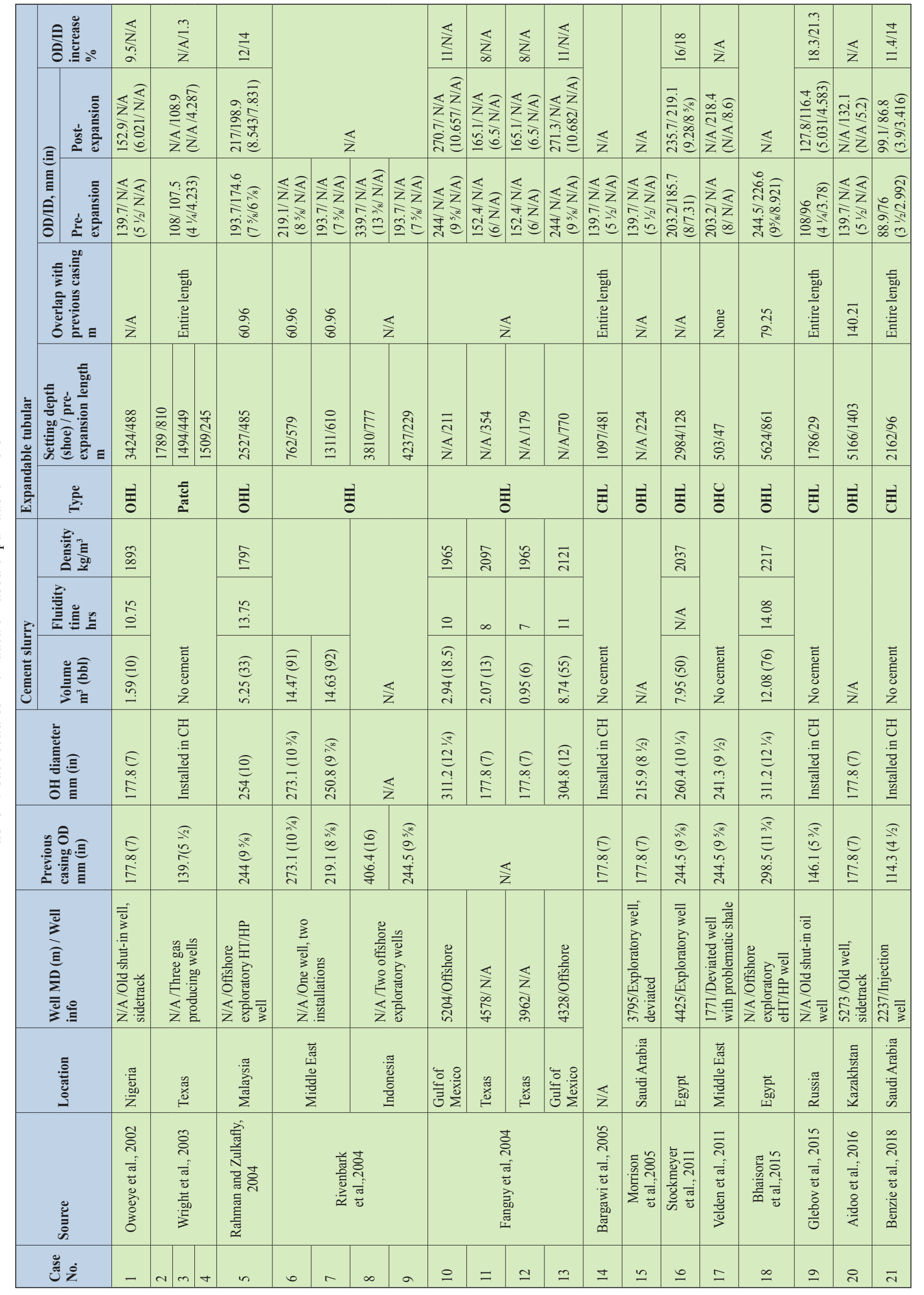


to characterize the compressibility and permeability of the cement matrix (Li et al., 2016).

In the example of the cementation of the deepest expandable liner into a well of extremely high pressure (112.4 $\mathrm{MPa} ; 16,300 \mathrm{psi}$ ), and temperature (BHST= $157^{\circ} \mathrm{C} ; 315^{\circ} \mathrm{F}$ ) in the Mediterranean Sea in the offshore of Egypt described by Bhaisora et al. (2015), a static gel strength of $48 \mathrm{~Pa}\left(100 \mathrm{lbf} / 100 \mathrm{ft}^{2}\right)$ was achieved within 20 hours and 44 minutes from the start of the test, and a static gel strength of $240 \mathrm{~Pa}\left(500 \mathrm{lbf} / 100 \mathrm{ft}^{2}\right)$ was recorded 21 hours and 26 minutes after the start of the test. Consequently, zero gel time is 18 hours, and the transition period is 42 minutes.

When cementing an expandable OHL, the cement slurry design should consider the long zero gel time required to allow for open hole liner expansion without degradation of the cement slurry. The static gel strength test is required to confirm a sufficiently long zero gel time for OHL expansion.

\subsubsection{Fluid loss}

A cement slurry must have low fluid loss to prevent premature dehydration during cementing. This is particularly important when cementing highly inclined or horizontal sections of a borehole since in these cases, longer intervals of permeable rocks are exposed to the cement slurry. The cement slurry fluid loss should normally be less than $100 \mathrm{ml} / 30 \mathrm{~min} / 6.9 \mathrm{MPa}$, but in the case of expandable OHL cementation, the recommended fluid loss value is the maximum $50 \mathrm{ml} / 30 \mathrm{~min} / 6.9 \mathrm{MPa}$ (50 cc/30 min/1000 psi) (Heathman et al., 2007). Excessive fluid loss is neither desirable nor permissible as it will change the other properties of the cement slurry (such as viscosity, thickening time, fluidity time, density) and may jeopardize the cementation process itself. The magnitude of change is directly related to the amount of fluid lost from the slurry. After the placement of a cement slurry in an annulus, the fluid phase will filter from the cement slurry to permeable formations, resulting in a reduction in the slurry volume and effective hydrostatic pressure, creating the potential for the migration of formation fluid into and through the cement column. Therefore, in order to prevent solid segregation during the placement of the cement slurry and to control the rate of fluid leakoff in the static state, it is necessary to control the fluid loss by adding appropriate fluid loss control additives (FLA) (eg. modified natural polymers, cellulosics, and vinylinic-based polymers).

\subsubsection{Compressive Strength}

Determination of the compressive strength of cement is performed according to the standard API procedure using an ultrasonic cement analyzer (UCA). To reduce wait-on-cement (WOC) and continue drilling, it is desirable to achieve the recommended minimum compressive strength of set cement, which is $3.45 \mathrm{MPa}$ (500 psi), as soon as possible. For this purpose, an additive for the development of early compressive strength is added to the cement slurry. When set Portland cements are exposed to temperatures above $110^{\circ} \mathrm{C}$, their properties will change, porosity will increase and compressive strength will decrease (a phenomenon known as strength retrogression). Typically, the strength retrogression of set cement is controlled by the addition of up to $35 \%$ silica sand or silica flour (Gaurina-Međimurec et al., 1994; Gaurina-Međimurec et al., 2017).

\section{Field examples of expandable tubular application}

Data for 21 case studies are shown in Table 2. The data includes, on a case-by-case basis, available location data, well measured depth (MD), previous casing outer diameter $(\mathrm{OD})$, open hole $(\mathrm{OH})$ diameter, expandable tubular data (type, setting depth, pre-expansion length, overlap with previous casing, pre-expansion and postexpansion OD and ID, increase of OD and ID in \%), and cement slurry data (volume, fluidity time and density).

The case studies given in Table 2 relate to the running of SET in onshore and offshore wells, including HPHT wells, deviated wells, re-entry/side-track wells.

Case studies cover different uses of SET and from different parts of the world as follows: 3 examples of running of patch (Texas; three gas producing wells), 15 examples of running expandable open hole liner (OHL) (14 cemented OHLs and 1 uncemented) (Malaysia, Middle East, Indonesia, Texas, Gulf of Mexico, Saudi Arabia, Egypt, and Kazakhstan), and 3 examples of running cased hole liner (Russia, Saudi Arabia; for one case no location was specified).

\section{Discussion}

The expandable internal casing patches from Table 2 were installed in three gas wells that had been shut-in due to corrosion leaks. The casing repairs were successful and the wells were restored to production. This confirms that the internal casing patch can be used as a costeffective alternative to the standard practice of squeeze cementing to repair casing leaks.

Based on the available data shown in Table 2, an OHL was installed after the running of the previous casing of the following diameters: $406.4 \mathrm{~mm}$ (16 in.), $349.25 \mathrm{~mm}$ (133/4 in.), $289.45 \mathrm{~mm}\left(11 \frac{3 / 4}{4}\right.$ in.), $273.05 \mathrm{~mm}\left(10^{3 / 4} \mathrm{in}\right.$.), $244.47 \mathrm{~mm}$ (95/8 in.), $201.07 \mathrm{~mm}(8 \% / 8 \mathrm{in}$.), and $177.8 \mathrm{~mm}$ (7 in.) (for four cases previous casing OD was not specified). Expandable OHLs had an outer diameter of 339.72 $\mathrm{mm}$ (13\% $/ 8$ in.), $244.47 \mathrm{~mm}$ (95/8 in.), $201.07 \mathrm{~mm}$ ( $85 \%$ in.), $203.2 \mathrm{~mm}$ (8 in.), $193.68 \mathrm{~mm}$ (75/8 in.), $152.4 \mathrm{~mm}$ (6 in.), $138.7 \mathrm{~mm}\left(5 \frac{1}{2} \mathrm{in}\right.$.) or $114.3 \mathrm{~mm}\left(4 \frac{1}{2} \mathrm{in}\right)$. OHLs were installed in the open hole, after increasing the drilled hole diameter using an underreamer or bi-center bit. The depth of OHL running (depth of liner shoe) ranged from 
$762 \mathrm{~m}$ to $5166 \mathrm{~m}$. The length of the OHL before expansion ranged from $29 \mathrm{~m}$ to $861 \mathrm{~m}$, while the overlap with the previous casing ranged from $60.69 \mathrm{~m}$ to $140.21 \mathrm{~m}$. The increase in the outer diameter (OD) of the OHL after expansion ranged from $8 \%$ to $16 \%$.

Data on the cement slurry shows that from $0.95 \mathrm{~m}^{3}$ to $14.6 \mathrm{~m}^{3}$ of the cement slurry, density from $1797 \mathrm{~kg} / \mathrm{m}^{3}$ to $2217 \mathrm{~kg} / \mathrm{m}^{3}$ were used for the cementation of expandable open hole liners. The fluidity time of the cement slurry was from 7 to 14 hours.

In the first of the three CHL cases listed in Table 2, a $138.7 \mathrm{~mm}\left(5^{1 / 2} \mathrm{in}\right.$.) liner (482 m long) was installed in a 7 in. casing. In the second case, a $107.95 \mathrm{~mm}$ ( $4 \frac{1}{4} \mathrm{in}$.) liner ( $29 \mathrm{~m}$ long) was installed in a $146.05 \mathrm{~mm} \mathrm{(5 \% /4} \mathrm{in.)} \mathrm{casing}$ in an old shut-in oil well in Russia. In the third case, an $88.9 \mathrm{~mm}\left(3^{1 / 2} \mathrm{in}\right.$.) liner (96 m long) was installed in a $114.3 \mathrm{~mm}\left(4_{1}^{1 / 2} \mathrm{in}\right.$.) casing in an injection well in Saudi Arabia. After running, the cased hole liner was expanded, thus restoring the damaged integrity of the casing.

Although the analysis covers a small number of examples from practice compared to the actual number of installed SETs worldwide, it nevertheless provides an overview of important information on the application and capabilities of this technology.

\section{Conclusions}

Based on an extensive review of the literature, it can be concluded that, after the first commercial running of solid expandable tubulars (SET) by Chevron on a well in the shallow waters of the Gulf of Mexico in November 1999 , this technology was successfully applied worldwide (e.g. China, Texas, Malaysia, Middle East, Indonesia, Saudi Arabia, Egypt, Russia, Kazakhstan and other countries). SETs are installed at ever-increasing depths and in more extreme conditions. SET technology is becoming indispensable in resolving many situations, especially those (e.g., ultra-deepwater wells) that require the running of more casing strings than there are casing sizes to drill the well to the target reservoir. In addition, it allows operators to apply slim-well design and drill monobore wells and achieve positive, technological, environmental, and economic aspects.

\section{References}

Aidoo, A., Berto, P.B., Gabdullina, M., Amanov, B., Park, M.,Connell, S., Orlandini, S. and Andonovski, G. (2016): Installation of Longest Openhole Solid Expandable Tubular Technology on a Deepening Well in Western Kazakhstan. SPE-181932-MS, SPE Russian Petroleum Technology Conference and Exhibition, Moscow, Russia, 24-26 October, 1-12. https://doi.org/10.2118/181932-MS

Al-Abri, O.S. and Pervez, T. (2013): Structural behavior of solid expandable tubular undergoes radial expansion process-Analytical, numerical, and experimental approaches.
International Journal of Solids and Structures, 50 (2013), 2980-2994.

Al-Umran, M. I., Al-Amri, K. M., Ahmed, I., Qasim, M., AlObaidi, I. A., Zhou, S., Sanders, T., Stephenson, D. and York, P. (2008): New 5 1/2-in. Solid Expandable Systems Provide Effective Technology for Successful Workover Project in Saudi Arabia. SPE-120797-MS, SPE Saudi Arabia Section Technical Symposium. Al-Khobar, Saudi Arabia, 10-12 May, 1-6. https://doi.org/10.2118/120797-MS

Badrack, R.P., Howie, W. and Hillis, D.J. (2005): Solid Expandable Technology? Testing and Application. NACE05124. CORROSION 2005, Houston, Texas, 3-7 April.

Bargawi, R. A., Zhou, S., Al-Umran, M. I. and Aghnim, W. A. (2005): Expandable Tubular Successfully Scab off Severe Casing Leaks. SPE-97357-MS, SPE/IADC Middle East Drilling Technology Conference and Exhibition. Dubai, United Arab Emirates, 12-14 September, 1-4. https://doi. org/10.2118/97357-MS

Ben Aissa, E. and Benabdelhafid, L. (2017): Resolving Trias issue in Nezla Field (Algeria) Using the Expandable casing (ABL), Case Study NZ-23. Dissertation: Professional Master, Faculty of Hydrocarbons, Renewable energies, and Earth and Universe Sciences, Uargla: Kasdi Merbah University, 1-73.

Benzie, S., Burge, P. and Dobson, A. (2000): Towards a monodiameter well - advances in expanding tubing technology. SPE 65184-MS, SPE European Petroleum Conference, Paris, France, 24-25 October, 1-7. https://doi.org/10. 2118/65184-MS

Benzie, S., Huey, T., Cooper, C. and Bufkin, C. (2018): Expandable Liner System Provides Option for Repairing Corroded, Small-Diameter Casing. SPE-192331-MS, SPE Kingdom of Saudi Arabia Annual Technical Symposium and Exhibition, Dammam, Saudi Arabia, 23-26 April 2018, 1-12, https://doi.org/10.2118/192331-MS

Bhaisora, D., Mohamed, S. and Awad, A. F. (2015): Learnings from Cementing the Deepest Expandable Casing under HP/HT Conditions in Mediterranean Offshore Egypt. SPE-175774-MS, SPE North Africa Technical Conference and Exhibition, Cairo, Egypt, 14-16 September, 1-16. https://doi.org/10.2118/175774-MS

Brunner, L. (2002): Expandable Casing Pipe Helps Oil Companies Drill to New Depths. The Fabricator.com, https://www. thefabricator.com/thefabricator/article/tubepipefabrication/ expanding-their-reach (accessed 16th August 2021)

Bybee, K. (2000): Expandable-Tubular Solutions. Journal of Petroleum Technology, 52(05), 47-48. https://doi:10. 2118/0599-0047-jpt

Cameron, J. R., Cooper, B. and Gusevik, R. (2013): Expandable Solid-Steel Liner Applications in the Marcellus. SPE165671-MS, SPE Eastern Regional Meeting. Pittsburgh, Pennsylvania, USA, 20-23 August, 1-13. https://doi.org/ 10.2118/165671-MS

Campo, D., Williams, C., Filippov, A., Cook, L., Brisco, D., Dean, B. and Ring, L. (2003): Monodiameter Drilling Liner - From Concept to Reality. SPE-79790-MS, SPE/IADC Drilling Conference, Amsterdam, Netherlands, 19-21 February, 1-15. https://doi.org/10.2118/79790-MS 
Carrillo, L. A., Gomez, J. C., Rivera, A. R., Figueroa, Y., Torres, P. C. and Clute-Melancon, D. D. (2016): Case History: Development of Expandable Liner Hanger for use in New Heavy Wall Casing Design in Gulf of Mexico. IADC/SPE 180645. IADC/SPE Asia Pacific Drilling Technology Conference, Singapore, 22-24 August, 1-12. https://doi. org/10.2118/180645-ms

Daigle, C.L., Campo, D.B., Naquin, C.J., Cardenas, R., Ring, L.M. and York, P.L. (2000): Expandable Tubulars: Field Examples of Application in Well Construction and Remediation. SPE-62958-MS, SPE Annual Technical Conference and Exhibition, Dallas, Texas, 1-4 October, 1-14. https://doi.org/10.2118/62958-MS

DeLange, R., Gandikota, R. and Osburn, S. (2011): A Major Advancement in Expandable Connection Performance, Enabling Reliable Gastight Expandable Connections. SPE Drilling \& Completion, 26(3), 412-418.

Dell, D.M., Jenkins, K., Noel, G. And Reque, J.V. (2019): The Value of Solid Expandable Tubulars in Cased-hole Environments. Solution Mining Research Institute (SMRI) Spring 2019 Technical Conference, New Orleans, Louisiana, USA, 8-9 April, 1-16.

Demong, K. and Rivenbark, M. (2003): Planning the Well Construction Process for the use of Solid Expandable Casing. SPE/IADC 85303, SPE/IADC Middle East Drilling Technology Conference and Exhibition, Abu Dhabi, UAE, 20-22 October, 1-10. https://doi.org/10.2118/85303-MS

Demong, K., Rivenbark, M. and Mason, D. (2004): Breakthroughs using Solid Expandable Tubulars to Construct Extended Reach Wells. SPE 87209-MS, IADC/SPE Drilling Conference, Dallas, Texas, USA, March 2-4, 1-12. https://doi.org/10.2118/87209-MS

Dupal, K., Naquin, C.J., Daigle, C., Cook,L. and York, P. (2000): Well Design With Expandable Tubulars Reduces Costs and Increases Success in Deepwater Applications. Deep Offshore Techology, 2000, 1-16.

Dupal, K.K., Campo, D.B., Lofton, J.E., Weisinger, D., Cook, R.L., Bullock, M.D., Grant, T.P. and York, P.L. (2001): Solid Expandable Tubular Technology-A Year of Case Histories in the Drilling Environment. SPE-67770-MS. SPE/IADC Drilling Conference, Amsterdam, Netherlands, February 27-March 1, 1-16. https://doi.org/10.2118/67770-MS

Escobar, C., Dean, B., Race, B. and Waddell, K. (2003): Increasing Solid Expandable Tubular Technology Reliability in a Myriad of Downhole Environment. SPE 81094, SPE Latin American and Caribbean Petroleum Engineering Conference, Port-of-Spain, Trinidad and Tobago, 27-30 April, 1-7. https://doi.org/10.2118/81094-MS

Fanguy, C.J., Muller, D.T. and Doherty, D.R. (2004): Improved Method of Cementing Solid Expandable Tubulars. SPE 90923, SPE Annual Technical Conference and Exhibition, Houston, Texas, USA, 26-29 September, 1-5. https://doi.org/10.2118/90923-MS

Filippov, A., Mack, R., Cook, L., York, P., Ring, L. and McCoy, T. (1999): Expandable Tubular Solutions. SPE 56500, SPE Annual Technical Conference and Exhibition, Houston, Texas, 3-6 October 1999, 1-16. https://doi. org/10.2118/56500-MS
Gaurina-Međimurec, N., Matanović, D. and Krklec, G. (1994). Cement Slurries for Geothermal Wells Cementing, Rudarsko-geološko-naftni zbornik(The Mining-Geological-Petroleum Engineering Bulletin), Vol. 6, No.1, 127134. https://hrcak.srce.hr/13715

Gaurina-Međimurec, N. (2005). Casing Drilling Technology, Rudarsko-geološko-naftni zbornik (The Mining-Geological-Petroleum Engineering Bulletin), Vol.17, No.1, 19-26. https://hrcak.srce.hr/5026

Gaurina-Međimurec, N., Simon, K., Matanović, D. and Pašić, B. (2006). Underbalanced Drilling Technology, Rudarskogeološko-naftni zbornik (The Mining-Geological-Petroleum Engineering Bulletin), Vol. 18, No.1, Zagreb, 81-95. https://hrcak.srce.hr/7337

Gaurina-Međimurec, N, Sedić, K., Čajić, A. and Matijević, A. (2017): Effect of Microblock on the Compressive Strength of Portland Cement at Elevated Temperatures. ASME paper OMAE2017-62455, Proceedings of the 36th International Conference on Ocean, Offshore and Arctic Engineering (OMAE17), Trondheim, Norway, June 25-30, 1-10. https://doi.org/10.1115/OMAE2017-62455

Gaurina-Međimurec, N., Pašić, B., Mijić, P. and Medved, I. (2021): Drilling Fluid and Cement Slurry Design for Naturally Fractured Reservoirs. Applied Sciences 2021, 11, 767., 1-30. https://doi.org/10.3390/app11020767

Grant, T. and Bullock, M. (2005): The Evolution od Expandable Tubular Technology: Lessons Learned Over Five Years. OTC 17442, Offshore Technology Conference, Houston, TX, USA, 2-5 May, 1-11. https://doi.org/ 10.4043/17442-MS

Gupta, Y. and Banerjee, S.N. (2007): The Application of Expandable Tubulars in Casing While Drilling. SPE105517, Latin American \& Caribbean Petroleum Engineering Conference, Buenos Aires, Argentina, 15-18 April, 1-7. https:// doi.org/10.2118/105517-MS

Gusevik, R. and Merritt, R. (2002): Reaching deep reservoir targets using solid expandable tubulars. SPE 77612, SPE Annual Conference and Exhibition, San Antonio, Texas, September 29-October 2, 1-13. https://doi.org/10.2118/ 77612-MS

Hayward, D., McCormick, J., Matice, M. and Dickinson, J. (2014): Expandable Liner Hangers in Off-Bottom Cementing Applications Reduce Cost and Increase Reliability: Regional Case History. SPE-169202-MS. SPE Bergen One Day Seminar, Bergen, Norway, 2 April, 1-7, https:// doi.org/10.2118/169202-MS

Heathman, J., Arredondo, E. and Olufowoshe, A. (2007): Enhanced Cementing Practices Address Unique Issues Found With Solid Expandable Tubular Applications. SPE/IADC 105227, SPE/IADC Drilling Conference, Amsterdam, The Netherlands, 20-22 February, 1-13. https://doi.org/10.2118/ 105227-MS

Innes, G., Metcalfe, P. and Hillis, D. (2004): Next Generation Expandable Liner Applications, IADC/SPE 88022, IADC/ SPE Asia Pacific Drilling Technology Conference and Exhibition, Kuala Lumpur, Malaysia, 13-15 September 2004. 1-6. https://doi.org/10.2118/88022-MS

Jennings, I.S. (2008): Dynamic Formations Rendered Less Problematic with Solid Expandable Technology. SPE- 
114678-MS, IADC/SPE Asia Pacific Drilling Technology Conference and Exhibition, Jakarta, Indonesia, 25-27 August. 1-10. https://doi.org/10.2118/114678-MS

Kupresan, D. (2014): Experimental assessment of expandable casing technology as a solution for microannular gas flow. LSU Master's Theses, 134 p. https://digitalcommons.lsu. edu/gradschool_theses/1265

Kupresan, D., Heathman, J. and Mileva Radonjic, M. (2014): Experimental Assessment of Casing Expansion as a Solution to Microannular Gas Migration. SPE-168056-MS, IADC/SPE Drilling Conference and Exhibition, Fort Worth, Texas, USA, 4-6 March, 1-11. https://doi.org/ 10.2118/168056-MS

Li, Z., Vandenbossche, J.M., Iannacchione, A.T.; Brigham, J.C., Kutchko, B.G. (2016): Theory-Based Review of Limitations with Static Gel Strength in Cement/Matrix Characterization. SPE Drilling \& Completion, June 2016, 145-158.

Marketz, F., Leuranguer, C., Welling, R. W. F. and Ogoke, V. (2005): Waterflood Appraisal-Well Delivery with Expandable Tubulars. IPTC-10345-MS, International Petroleum Technology Conference. Doha, Qatar, 21-23 November, 1-9. https://doi.org/10.2523/IPTC-10345-MS

Mason, D., Duhrkopf, D. J., Morgan, Q. P., McGeoch, A. P. and Jones, C. (2011): The Use of Slotted Expandable Liners in Multizone Openhole Frac-Packs: A New Completion Concept. SPE 147044, SPE Annual Technical Conference and Exhibition, Denver, Colorado, USA, October 30-November 2, 1-10. https://doi.org/10.2118/147044-MS

McCormick, J., Carter, A. and Johnson, R. (2013): Large Bore Expandable Liner Hangers for Offshore and Deepwater Applications Reduces Cost and Increases Reliability: GOM Case History. SPE/IADC Drilling Conference, Amsterdam, The Netherlands, March 2013, 1-8, https://doi. org/10.2118/163410-MS

Merritt, J.W. (2005): Premixed Cement Slurry Solves Problems Associated With Conventional Oilwell Cementing. SPE 93897, SPE Production and Operations Symposium, Oklahoma City, OK, USA, 17-19 April, 1-5. https://doi. org/10.2118/93897-MS

Metcalfe, P., Martyn, K. and Aitken, S. (2000): Successful Isolation of an Overpressured Gas Zone Using an Expandable Drilling Liner. IADC/SPE 62749, IADC/SPE Asia Pacific Drilling Technology. Kuala Lumpur, Malaysia, 11-13 September, 1-6. https://doi.org/10.2118/62749-MS

Miessner, D.J., Ochuko, E., Wenting, W., Hopkins, C.J., Nijveld, E. and Kaschke, M. (2006): Solid Expandable Tubular Technology: Case histories of value adding \& enabling applications in Sabah Deepwater. SPE-101222-MS, IADC/SPE Asia Pacific Drilling Technology Conference and Exhibition, Bangkok, Thailand, 13-15 November, 1-7. https://doi.org/10.2118/101222-MS

Morris, T. C., Bidi, M. Z., Elmarsafawi, Y., Nair, D., Said, R., Tugcu, R. and Ong, J. (2004): Innovative Remedial Cementing Solution Provides Annular Isolation in Duyong B-4, Petronas Carigali. IADC/SPE Asia Pacific Drilling Technology Conference and Exhibition. Kuala Lumpur, Malaysia, 13-15 September, 1-11. https://doi.org/10. 2118/88017-ms
Morrison, W., Baggal, Z., Baxendale, B. and Boudreaux, R. (2005). Optimizing Wellbore Design Using Solid Expandable Tubular and Bi-center Bit Technologies, SPE 92886, The $14^{\text {th }}$ SPE Middle East Oil\&Gas Show and Conference, Bahrain, 12-15 March,1-9. https://doi. org/10.2118/92886-MS

Nor, N. M., Edmund, H. and Chin, H.-V. (2002): Transforming Conventional Wells in Mature Basins to Modern Bigbore Producers by Applying Solid Expandable Tubulars (SET). SPE-77940-MS, SPE Asia Pacific Oil and Gas Conference and Exhibition, Melbourne, Australia, 8-10 October, 1-8. https://doi.org/10.2118/77940-MS

Owoeye, O.O., Aihevba, L.O., Hartmann, R.A. and Ogoke, V.C. (2000): Optimization of Well Economics by Application of Expandable Tubular Technology. SPE/IADC 59142, SPE/IADC Drilling Conference, New Orleans, Louisiana, 23-25 February, 1-18. https://doi.org/10.2118/ 59142-MS

Owoeye, O.O., Onwuta, V.O., Erivwo, O.E., Griffith, J. and Nida, R. (2002): Use of Settable Spotting Fluid Improves Expandable Casing Process - Case History". SPE 77751, SPE Annual Technical Conference and Exhibition, San Antonio, Texas, USA, 29 September-2 October, 1-11. https://doi.org/10.2118/77751-MS

Park, M., Teasdale, P. and Cowling, M. (2015): Application of Uncemented Solid Expandable Liner for Combined Openhole Isolation and Casing Repair. SPE-173134-MS, SPE/ IADC Drilling Conference and Exhibition, London, England, UK, 17-19 March, 1-13. https://doi.org/10.2118/ 173134-MS

Pašić, B., Gaurina-Međimurec, N. and Matanović, D. (2007). Wellbore Instability: Causes and Consequences, Rudarskogeološko-naftni zbornik (The Mining-Geological-Petroleum Engineering Bulletin), Vol. 19, No.1, 87-98. https:// hrcak.srce.hr/19296

Rae, P. and Johnston, N. (1996): Liquid Cement Premix for Improved Abandonment and Workover Operations. SPE 36477, SPE Annual Technical Conference and Exhibition, Denver, Colorado, 6-9 October, 637-643. https://doi. org/10.2118/36477-MS

Rahman, A.R. and Zulkafly, A.H. (2004): Issues and Solutions for Cementing Expandable Liners: A Case History. IADC/ SPE 87211, IADC/SPE Drilling Conference, Dallas, Texas, USA, 2-4 March, 1-13. https://doi.org/10.2118/87211-MS

Rivenbark, M., Demong, K., Mulhem, S. S. and Olivera, G. (2004): Solid Expandable Tubular Technology: The Value of Planned Installation vs. Contingency. SPE-90821-MS, SPE Annual Technical Conference and Exhibition. Houston, Texas, U.S.A., 26-29 September, 1-8. https://doi. org/10.2118/90821-MS

Ruan, C. G. and Maurer, W. C. (2005): Analytical Model for Casing Expansion. SPE-92281-MS, SPE/IADC Drilling Conference, Amsterdam, Netherlands, 23-25 February, 1-11. https://doi.org/10.2118/92281-MS

Ruggier, M., Benzie, S., Urselmann, R., Mosser, H. and van Noort, R. (2001): Advances in expandable tubing - a case history. SPE/IADC 67768, SPE/IADC Drilling Technology Conference, Amsterdam, Netherlands, 27 February-1 March, 1-9. https://doi.org/10.2118/67768-MS 
Sanders, T., Gusevik, R., Nida, R. and Griffith, J. (2003): Practices for Providing Zonal Isolation in Conjunction with Expandable Casing Jobs - Case Histories. High-tech Wells Conference and Exhibition Galveston, Texas, USA, 11-13 February.

Schultz, D.,Pollard, G., Fuller, G., Langlinais, J., Serio, M. And Bradley, J. (2008): Optimized Deepwater Cement Design for Record-Length Expandable Liner. IADC/SPE 112626, IADC/SPE Drilling Conference, Orlando, Florida, USA, 4-6- March, 2-14. https://doi.org/10.2118/112626-MS

Shaikh, A., Duran, R.C., Abouelnaaj, K.K., Fritsch, J., Andrews, S. and Baker, R. (2013): First Installation of 16-in. Solid Expandable Liner Solves Shallow Drilling Problems; Opens New Doors for Hole Size Preservation. SPE/ IADC 166701-MS, SPE/IADC Middle East Drilling Technology Conference and Exhibition, Dubai, UAE, 7-9 October, 1-10. https://doi.org/10.2118/166701-MS

Shiri, Y., and Shiri, A. (2021): Discrete Fracture Network (DFN) Modelling of Fractured Reservoir Based on Geomechanical Restoration, a Case Study in the South of Iran. Rudarsko-geološko-naftni zbornik (The Mining-Geological-Petroleum Engineering Bulletin), 36(4). https:// doi.org/10.17794/rgn.2021.4.12

Simon, K., Gaurina-Međimurec, N. and Pašić, B. (2005): Drilling Fluids Differential Sticking Tendency Determination, Rudarsko-geološko-naftni zbornik (The Mining-Geological-Petroleum Engineering Bulletin), Vol.17, No.1, 3135. https://hrcak.srce.hr/7397

Silva, M.G.P., Martins, A.L., Barbarosa, B.C. and Garcia, H.Jr. (1996): Designing Fluid Velocity Profiles for Optimal Primary Cementing. SPE 36136-MS, SPE Latin America/ Caribbean Petroleum Engineering Conference, Port-ofSpain, Trinidad, 23-26 April, 605-613. https://doi.org/ 10.2118/36136-MS

Stewart, R.B., Marketz, F., Lohbeck, W.C.M., Fischer, F.D., Daves, W., Rammerstorfer, F.G. and Bohm, H.J. (1999): Expandable wellbore tubulars. SPE-60766-MS, SPE Technical Symposium, Dhahran, Saudi Arabia, 16 October, 1-33. https://doi.org/10.2118/60766-MS

Stringer, J.A. and Farley, D.B. (2013): The Evolution of Expandables: A New Era of Monobore Expandable Wellconstruction Systems. SPE 164171, SPE Middle East Oil and Gas Show and Conference, Manama, Bahrain, 10-13 March, 1-8. https://doi.org/10.2118/164171-MS

Tao, L. (2015): Solid expandable tubular patching technique for high-temperature and high-pressure casing damaged wells. Petroleum Exploration and Development., 42(3), June 2015, 408-413.

Waddell, K. and Schuurmans, R. (2004): Installation of Solid Expandable Tubular Systems Through Milled Casing Windows. SPE-87208-MS, IADC/SPE Drilling Conference, Dallas, Texas, 2-4 March, 1-10. https://doi.org/10.2118/ 87208-MS
Wold, A., Berge, F., Paulsen, E. and Baker, R. (2020): Innovative Use of Solid Expandable Liners as Host in Multilateral Well Construction Applications. SPE-201271-MS, SPE Annual Technical Conference and Exhibition, October 26-29, (originally scheduled to be held in Denver, Colorado, USA, 5 - 7 October 2020). Virtual due to Covid-19, October 26-29, 1-13. https://doi.org/10.2118/ 201271-MS

Wright, J. C., Moore, M. J. and Winters, W. J. (2003): Expandable Tubular Casing Repairs: Four Case Histories. SPE 84049, SPE Annual Technical Conference and Exhibition, Denver, Colorado, USA, 5-8 October, 1-10. https://doi. org/10.2118/84049-MS

\section{Internet sources:}

ULR 1: https://www.enventuregt.com/zh-hans/node/740 SET ${ }^{\circledR}$ Expandable Bow-Spring Centralized Liner Reduces NPT ((accessed 29th September 2021)

ULR 2: https://www.eventuregt.com SET® Openhole Liner System (accessed 29th September 2021)

ULR 3: https://www.enventuregt.com/en/technical-library/ samedrift $\%$ E2\%84\%A2-openhole-liner SameDriftTM Openhole Liner (accessed 29th September 2021)

ULR 4: https://www.weatherford.com/en/documents/brochure /products-and-services/drilling/metalskin-openhole-linersystem/ MetalSkin Openhole Liner System (accessed 29th September 2021)

ULR 5: https://www.enventuregt.com/en/products-solutions/ technology/eseal\%E2\%84\%A2-intervention-solutions/eseal-liner ESeal ${ }^{\mathrm{TM}}$ Liner (accessed 29th September 2021)

ULR 6: https://www.weatherford.com/en/documents/technical-specification-sheet/products-and-services/drilling/ metalskin-cased-hole-liner-system/ MetalSkin ${ }^{\circledR}$ CasedHole Liner System (accessed 29th September 2021)

ULR 7: https://www.halliburton.com/en/completions/wellcompletions/liner-hangers VersaFlex ${ }^{\circledR}$ Expandable Liner Hanger System and Liner Hanger Systems - Catalog (accessed 29th September 2021)

ULR 8: https://www.weatherford.com/en/documents/brochure /products-and-services/intervention-and-abandonment/ homco-casing-patch/ HOMCO®CASING PATCH, Restoring casing integrity with a permanent steel seal (accessed 29th September 2021)

ULR 9: https://www.weatherford.com/getattachment/37db 1f0f-8f13-48fe-a73f-445b98359afa/Expandable-Completions-Systems.pdf Expandable Completions Systems (accessed 29th September 2021)

ULR 10: https://www.yumpu.com/en/document/read/21783 756/poroflexr-expandable-screen-completion-systemshalliburton PoroFlex ${ }^{\circledR}$ Expandable Screen Completion System (accessed 29th September 2021) 


\section{SAŽETAK}

\section{Primjena proširivih cijevi u naftnoj industriji}

Razvoj tehnologije proširivanja cijevi i proširivih proizvoda (lajner za otvoreni kanal, obloga za otvoreni kanal, lajner za zacijevljeni kanal, vješalica lajnera, unutarnja zakrpa zaštitnih cijevi itd.) omogućili su operaterima da na nov način planiraju projektiranje bušotine i riješe različite probleme koji nastaju tijekom bušenja i eksploatacije na kopnu i moru. Uključivanjem u dizajn bušotine proširivoga lajnera za otvoreni kanal, lajnera i/ili zakrpe za otvoreni kanal unutarnjega promjera koji je jednak unutarnjemu promjeru prethodno ugrađene kolone, moguće je dizajnirati bušotinu manjega promjera i/ili riješiti neželjene situacije koje se javljaju tijekom bušenja kroz problematične zone s minimalnim smanjenjem promjera kanala bušotine te pristupiti ležištima ugljikovodika što ne bi bilo moguće ekonomično postići primjenom konvencionalne tehnologije. Ugradnjom proširivoga lajnera ili zakrpe u kolonu zaštitnih cijevi, radi izoliranja korodiranih dijelova kolone ili zatvaranja starih perforacija, moguće je produljiti životni vijek proizvodne bušotine, povećati konačni iscrpak ugljikovodika te ubrzati povratak ulaganja. Cilj je rada sustavno pregledati relevantnu literaturu i dati pregled tehnologije proširivanja cijevi te njihove primjene u naftnoj industriji s posebnim osvrtom na cementiranje proširivoga lajnera u otvorenome kanalu bušotine. Detaljno su analizirani dostupni podatci za 21 primjer primjene proširivih cijevi u bušotinama na kopnu i moru. Na temelju opsežnoga pregleda literature i analiziranih podataka može se zaključiti da se tehnologija proširivanja cijevi uspješno primjenjuje u cijelome svijetu i da se proširivi lajneri promjera od 114,3 mm do 339,72 mm ugrađuju u bušotine do sve većih dubina (do $5166 \mathrm{~m}$ ) i u sve ekstremnijim bušotinskim uvjetima.

\section{Ključne riječi:}

proširive cijevi, vreteno za proširivanje, proširivi lajner, vješalica lajnera, cementacija

\section{Author's contribution}

Nediljka Gaurina-Međimurec (1) (PhD, Full Professor) provided an overview of solid expandable tubular technology and its applications in practice. Pavao Mesarić (2) (Master of Engineering in Petroleum Engineering) provided an overview of case studies and participated in writing the paper. 